\title{
GLACIER RUNOFF AND SEDIMENT TRANSPORT AND DEPOSITION EKLUTNA LAKE BASIN, ALASKA
}

by Timothy P. Brabets

U.S. GEOLOGICAL SURVEY

Water-Resources Investigations Report 92-4132

Prepared in cooperation with the MUNICIPALITY OF ANCHORAGE 


\title{
U.S. DEPARTMENT OF THE INTERIOR
}

\author{
MANUEL LUJAN, JR., Secretary \\ U.S. GEOLOGICAL SURVEY
}

Dallas L. Peck, Director

For additional information write to:

District Chief

U.S. Geological Survey 4230 University Drive, Suite 201 Anchorage, Alaska 99508-4664
Copies of this report can be purchased from:

U.S. Geological Survey Books and Open-File Reports Section Federal Center, Box 25425

Denver, Colorado 80225 


\section{CONTENTS}

Page

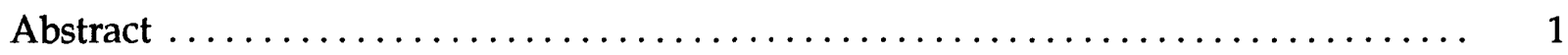

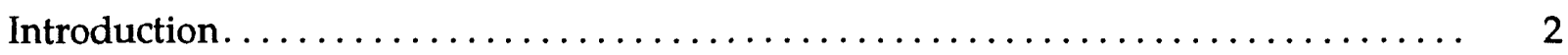

Purpose and scope $\ldots \ldots \ldots \ldots \ldots \ldots \ldots \ldots \ldots \ldots \ldots \ldots \ldots \ldots \ldots \ldots \ldots \ldots, 2$

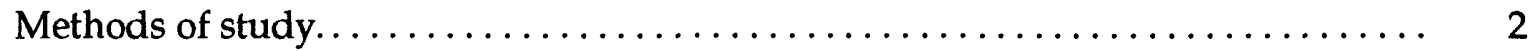

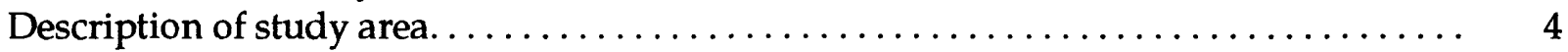

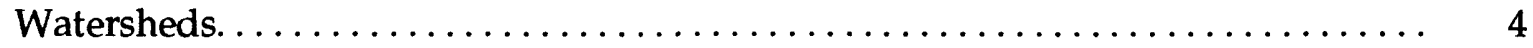

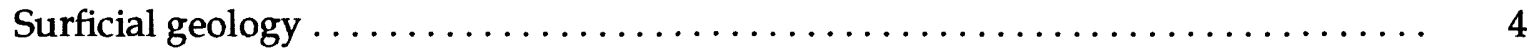

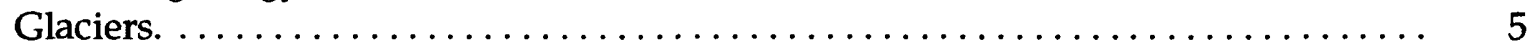

Eklutna Lake.......................................... 5

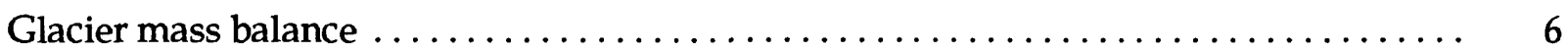

Glacier runoff $\ldots \ldots \ldots \ldots \ldots \ldots \ldots \ldots \ldots \ldots \ldots \ldots \ldots \ldots \ldots, 12$

Streamflow characteristics. $\ldots \ldots \ldots \ldots \ldots \ldots \ldots \ldots \ldots \ldots \ldots \ldots \ldots \ldots \ldots \ldots \ldots, 12$

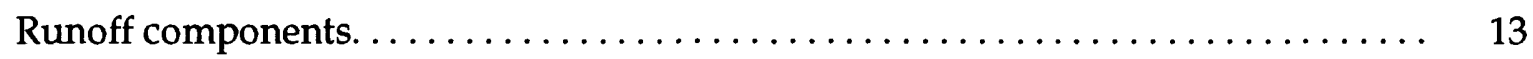

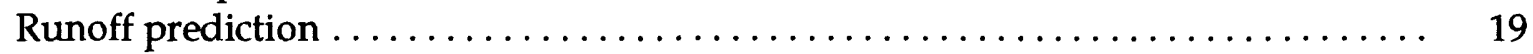

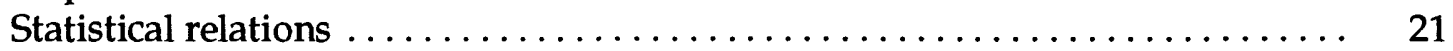

Precipitation-Runoff Modeling System . . . . . . . . . . . . . . . . . 22

Sediment transport and deposition $\ldots \ldots \ldots \ldots \ldots \ldots \ldots \ldots \ldots \ldots \ldots \ldots \ldots, 26$

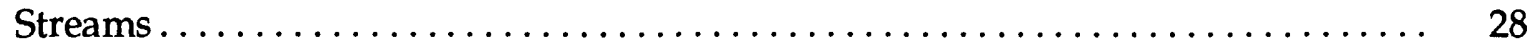

Suspended-sediment discharge $\ldots \ldots \ldots \ldots \ldots \ldots \ldots \ldots \ldots \ldots \ldots, 28$

Bedload discharge. $\ldots \ldots \ldots \ldots \ldots \ldots \ldots \ldots \ldots \ldots \ldots \ldots \ldots, \quad 32$

Eklutna Lake $\ldots \ldots \ldots \ldots \ldots \ldots \ldots \ldots \ldots \ldots \ldots \ldots \ldots \ldots \ldots \ldots \ldots, \quad 37$

Delta progradation $\ldots \ldots \ldots \ldots \ldots \ldots \ldots \ldots \ldots \ldots \ldots \ldots \ldots \ldots, \quad 37$

River plume dispersion $\ldots \ldots \ldots \ldots \ldots \ldots \ldots \ldots \ldots \ldots \ldots \ldots \ldots, \quad 38$

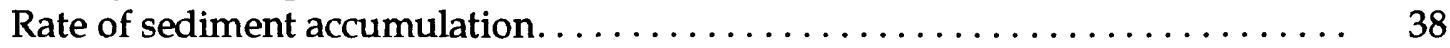

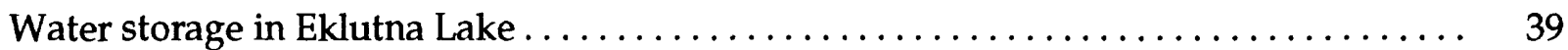

Summary and conclusions $\ldots \ldots \ldots \ldots \ldots \ldots \ldots \ldots \ldots \ldots \ldots \ldots \ldots \ldots \ldots \ldots \ldots, 43$

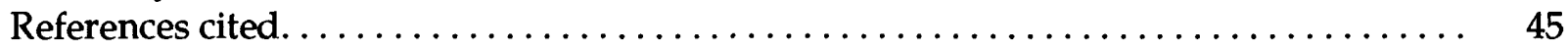

Glossary $\ldots \ldots \ldots \ldots \ldots \ldots \ldots \ldots \ldots \ldots \ldots \ldots \ldots \ldots \ldots \ldots \ldots \ldots \ldots \ldots \ldots \ldots \ldots, 47$

\section{ILLUSTRATIONS}

Plate 1. Map showing geology and location of hydrologic data sites in the In Pocket Eklutna Lake drainage basin, southcentral Alaska

Figure 1. Map showing Eklutna Lake and vicinity..................... 3

2. Photograph of Eklutna Lake, $1987 \ldots \ldots \ldots \ldots \ldots \ldots \ldots \ldots \ldots \ldots . \quad 4$

3. Graphs of area-altitude distribution of the East Fork and West Fork Eklutna Creeks basins............................. 5

4. Photograph of headwaters of East Fork Eklutna Creek, $1987 \ldots \ldots \ldots \ldots .6$

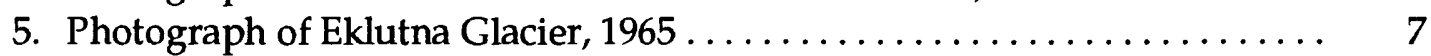

6. Graph of water temperature profiles of Eklutna Lake showing: A, summer stratification and $B$, winter inverse stratification $\ldots \ldots \ldots \ldots \ldots \ldots \ldots, \quad 8$

7. Map showing bathymetry of Eklutna Lake and locations of core samples. 


\section{ILLUSTRATIONS--Continued}

Figure 8. Graphs of characteristics of Eklutna Lake, 1986 water year, showing:

Page

A, monthly inflow; and B, monthly lake level ................. 10

9. Graph of ablation of snow and ice on Eklutna Glacier, 1985 water

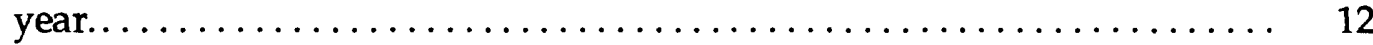

10. Hydrograph showing streamflow of East Fork and West Fork Eklutna Creeks, July 28-30, 1985.

11-12. Hydrographs showing daily streamflow and air temperature for East Fork and West Fork Eklutna Creeks:

11. 1985 and 1986 water years $\ldots \ldots \ldots \ldots \ldots \ldots \ldots \ldots \ldots \ldots \ldots \ldots . \ldots \ldots$

12. 1987 and 1988 water years .......................... 15

13-14. Graphs showing monthly runoff for East Fork and West Fork Eklutna Creeks:

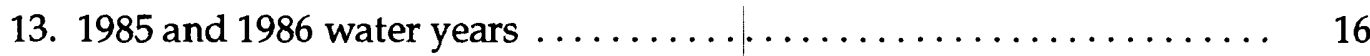

14. 1987 and 1988 water years ......................... 17

15. Graph showing altitude distribution of precipitation as rain and snow, accumulation, icemelt, snowmelt, and runoff for a glacier in southcentral Alaska .........................................

16-17. Graphs showing observed daily mean streamflow and daily mean streamflow predicted from statistical equations, June to September 1985-88:

16. East Fork Eklutna Creek. ............................ 21

17. West Fork Eklutna Creek......................... 21

18. Diagrams showing West Fork and East Fork Eklutna Creek basins partitioned into hydrologic response units....................

19-20. Hydrographs showing observed daily mean streamflow and daily mean streamflow simulated from the PRMS, June to September 1986-88:

19. East Fork Eklutna Creek............................. 25

20. West Fork Eklutna Creek. ......................... 26

21-22. Graphs showing daily mean streamflow and suspended-sediment concentration, June to September 1985, 1986, and 1987:

21. East Fork Eklutna Creek. . . . . . . . . . . . . . . . . . . . . . . 29

22. West Fork Eklutna Creek. ....................... 30

23. Graphs showing suspended-sediment discharge and water discharge for East Fork and West Fork Eklutna Creeks ....................

24. Graphs showing suspended-sediment loads for East Fork and West Fork Eklutna Creeks, June to September 1985, 1986, and 1987 ......

25. Graphs showing particle-size distribution and median diameter of bedload for East Fork and West Fork Eklutna Creeks ...............

26. Graphs showing bedload discharge and water discharge for East Fork and West Fork Eklutna Creeks. ........................ 35

27. Graphs showing bedload for East Fork and West Fork Eklutna Creeks, June to September 1985, 1986, and 1987. . .

28. Diagram showing types of sediment layers formed by inflow to

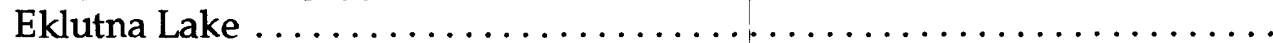

29. Graphs of profiles of density current in Eklutna Lake at various times showing: A, underflow; $B$, no density current; $C$, overflow; and $\mathrm{D}$, interflow 


\section{TABLES}

Table 1. Morphometry of Eklutna Lake at 860.00 feet water-surface altitude ....... 8

2. Snow density at various altitudes on Eklutna Glacier ............. 10

3. Mass balance measurements on Eklutna Glacier, 1985-88 . . . . . . . . . . . . 11

4. Precipitation measured in the Eklutna Lake basin, $1985-88 \ldots \ldots \ldots \ldots \ldots \ldots$

5. Estimated distribution of unit runoff of the West Fork and East Fork Eklutna Creeks, June to September, $1985-88 \ldots \ldots \ldots \ldots \ldots \ldots \ldots \ldots \ldots$

6. Calculated and simulated icemelt for East Fork and West Fork Eklutna Creeks, June to September, $1986-88 \ldots \ldots \ldots \ldots \ldots \ldots \ldots \ldots \ldots \ldots \ldots \ldots \ldots \ldots$

7. Observed and simulated average monthly discharges for East Fork and West Fork Eklutna Creeks, June to September, 1986-88 . . . . . . . . . 27

8. Active storage of Eklutna Lake. . . . . . . . . . . . . . . . . 40

9. Changes in storage, outflow, and inflow for Eklutna Lake, 1985-88. . . . . 42

10. Risks of failure to supply withdrawal rates during the year at Eklutna Lake........................................... 44

\section{CONVERSION FACTORS, VERTICAL DATUM, AND ABBREVIATED WATER-QUALITY UNITS}

$\begin{array}{lcl}\text { Multiply } & \text { By } & \text { To obtain } \\ \text { inch (in.) } & 25.4 & \text { millimeter } \\ \text { foot (ft) } & 0.3048 & \text { meter } \\ \text { mile }(\mathrm{mi}) & 1.609 & \text { kilometer } \\ \text { square mile }\left(\mathrm{mi}^{2}\right) & 2.590 & \text { square kilometer } \\ \text { acre-foot }(\mathrm{acre}-\mathrm{ft}) & 1,233 & \text { cubic meter } \\ \text { cubic foot per second }\left(\mathrm{ft}^{3} / \mathrm{s}\right) & 0.02832 & \text { cubic meter per second } \\ \text { cubic foot per second per day }\left[\left(\mathrm{ft}^{3} / \mathrm{s}\right) / \mathrm{d}\right] & 0.02832 & \text { cubic meter per second per day } \\ \text { ton, short } & 0.9072 & \text { megagram } \\ \text { ton per square mile }\left(\mathrm{ton} / \mathrm{mi}^{2}\right) & 0.3503 & \text { megagram per square kilometer } \\ \text { pound per cubic foot }\left(\mathrm{lb} / \mathrm{ft}^{3}\right) & 16.02 & \text { kilogram per cubic meter } \\ \text { million gallons per day }\left(\mathrm{Mgal}^{2} / \mathrm{d}\right) & 0.04381 & \text { cubic meter per second } \\ & & \\ \text { degree Fahrenheit }\left({ }^{\circ} \mathrm{F}\right) & { }^{\circ} \mathrm{C}=5 / 9 \times\left({ }^{\circ} \mathrm{F}-32\right) & \text { degree Celsius }\left({ }^{\circ} \mathrm{C}\right)\end{array}$

Other abbreviations in this report are:

$\mathrm{g} / \mathrm{cm}^{3}$, gram per cubic centimeter $\mathrm{mg} / \mathrm{L}$, milligram per liter

\section{Sea level:}

In this report "sea level" refers to the National Geodetic Vertical Datum of 1929 (NGVD of 1929), a geodetic datum derived from a general adjustment of the first-order level nets of both the United States and Canada, formerly called Sea Level Datum of 1929. 


\title{
GLACIER RUNOFF AND SEDIMENT TRANSPORT AND DEPOSITION \\ EKLUTNA LAKE BASIN, ALASKA
}

\author{
by Timothy P. Brabets
}

\begin{abstract}
Two streams in the Eklutna Lake basin, the East Fork Eklutna Creek and the West Fork Eklutna Creek, provided more than 80 percent of the water to Eklutna Lake during the period of study, 1985-88. The East Fork Eklutna Creek drains an area of 38.2 square miles, of which 7.6 square miles are glaciers; the West Fork Eklutna Creek drains an area of 25.4 square miles, of which 12.2 square miles are glaciers.
\end{abstract}

For water years 1986, 1987, and 1988, total runoff ranged from 43 to 53 inches in the East Fork Eklutna basin and from 55 to 58 inches in the West Fork Eklutna basin. More than 75 percent of the runoff from the East Fork Eklutna basin and more than 85 percent of the runoff from the West Fork Eklutna basin occurred from June to September. The principal components of runoff were snowmelt (52-64 percent), rainfall (27-33 percent), and icemelt (6-19 percent).

From 1985-87, total annual sediment load transported past the East Fork and West Fork Eklutna Creek gaging stations ranged from 22,300 to 36,500 tons and from 46,700 to 54,600 tons, respectively. Bedload constitutes between 14 and 26 percent of the total sediment transported past the East Fork station and between 7 and 10 percent of the total sediment transported past the West Fork station. Most of the suspended sediment was composed of silt and clay; most of the bedload consisted of coarse sand and fine gravel.

Eklutna Lake has an active storage capacity of 138,000 acre-feet at a water-surface altitude of 860.00 feet above sea level. Sedimentation in the lake is characterized by delta progradation and river plume dispersion. Coarse sediment accumulates at a rate of about 5 acre-feet per year near the delta of the lake and suspended sediment accumulates at a rate of 74 acre-feet per year throughout the lake. A distinct interflow (density current) is present in the lake from late June through September.

Two U.S. Geological Survey computerbased models were used in this study: the Precipitation-Runoff Modeling System (PRMS) and a storage frequency model. Although PRMS was able to predict the amount of icemelt, it underpredicted daily runoff. The storage frequency model indicates that at an outflow rate of 450 cubic feet per second, the probability of the storage capacity of Eklutna Lake being exceeded is less than 10 percent, and that May and June are the months when the capacity would most likely be exceeded. 


\section{INTRODUCTION}

In March 1974, Congress authorized the Metropolitan Anchorage Urban Study (MAUS) to identify and solve the water and related land resources problems and development needs of the Anchorage metropolitan area. One finding of MAUS was the lack of a developed and dependable water supply for the projected future population of the Municipality of Anchorage (U.S. Army Corps of Engineers, 1979). The MAUS further recommended that diversion of water from Eklutna Lake (fig. 1) would be the most feasible solution to solving Anchorage's long-term water-supply problem. Thus, in 1984 construction began on a $\$ 200$ million project to bring Eklutna Lake water to Anchorage. This project consisted of a 32-mile gravity-feed pipeline system, two energy-recovery stations, a water-treatment plant and clearwell, and an 8,500-foot tunnel. The project was completed in 1988.

Communities along the Eklutna pipeline such as Peters Creek, Chugiak, and Eagle River will most likely use Eklutna Lake water by the year 2000. Also, it is expected that water use in the Anchorage area will increase, placing additional demands on the municipality's publicwater supply. Although the hydrologic data that were available during the MAUS study provided sufficient information to indicate that Eklutna Lake would provide enough water for the near future, some more specific questions remained. For example, the rate and volume of runoff from the glacierized and snow-covered areas of Eklutna Lake basin vary both seasonally and annually, which would affect operation of a water-supply reservoir. Additionally, glacier-fed streams have high concentrations of suspended sediment during the snowmelt and icemelt seasons, which would require special operating procedures for a water-treatment plant supplied by the lake. Sedimentation on the lake bottom could reduce the storage capacity of the lake.
Thus, in 1985, the U.S. Geological Survey, in cooperation with the Municipality of Anchorage, began a 4-year study of the glacial runoff and sedimentation characteristics of Eklutna Lake.

\section{Purpose and Scope}

This report contains the results of the study of the Eklutna Lake basin. The study had the following objectives: (1) to determine the timing and amount of runoff from rainfall, snowmelt, and icemelt; (2) to determine the amount of sediment that enters Eklutna Lake and how the sediment (both suspended and bed) moves into, within, and out of Eklutna Lake; and (3) to determine the storage characteristics of Eklutna Lake.

\section{Methods of Study}

To accomplish the study objectives, the following approach was taken. Intensive field work was done on Eklutna Glacier. This included digging snow pits on the glacier to determine snow density and water equivalent at various locations and at different times. Stakes were installed at different locations on the glacier (plate 1) to allow measurement of melt and accumulation of ice and snow. A climatological station was installed on the glacier (plate 1) to collect solar radiation, air temperature, precipitation, wind speed, and wind direction data. These data were also used to define the accumulation and melting characteristics of snow and ice on Eklutna Glacier and surrounding glaciers and snowfields.

Streamflow information (U.S. Geological Survey, 1986-89) was collected at the major inflow streams to Eklutna Lake: East Fork Eklutna Creek (gaging station No. 15277600) and West Fork Eklutna Creek (gaging station No. 15277800) (plate 1). The data were used to determine the quantity of water that enters Eklutna Lake and the storage characteristics of 


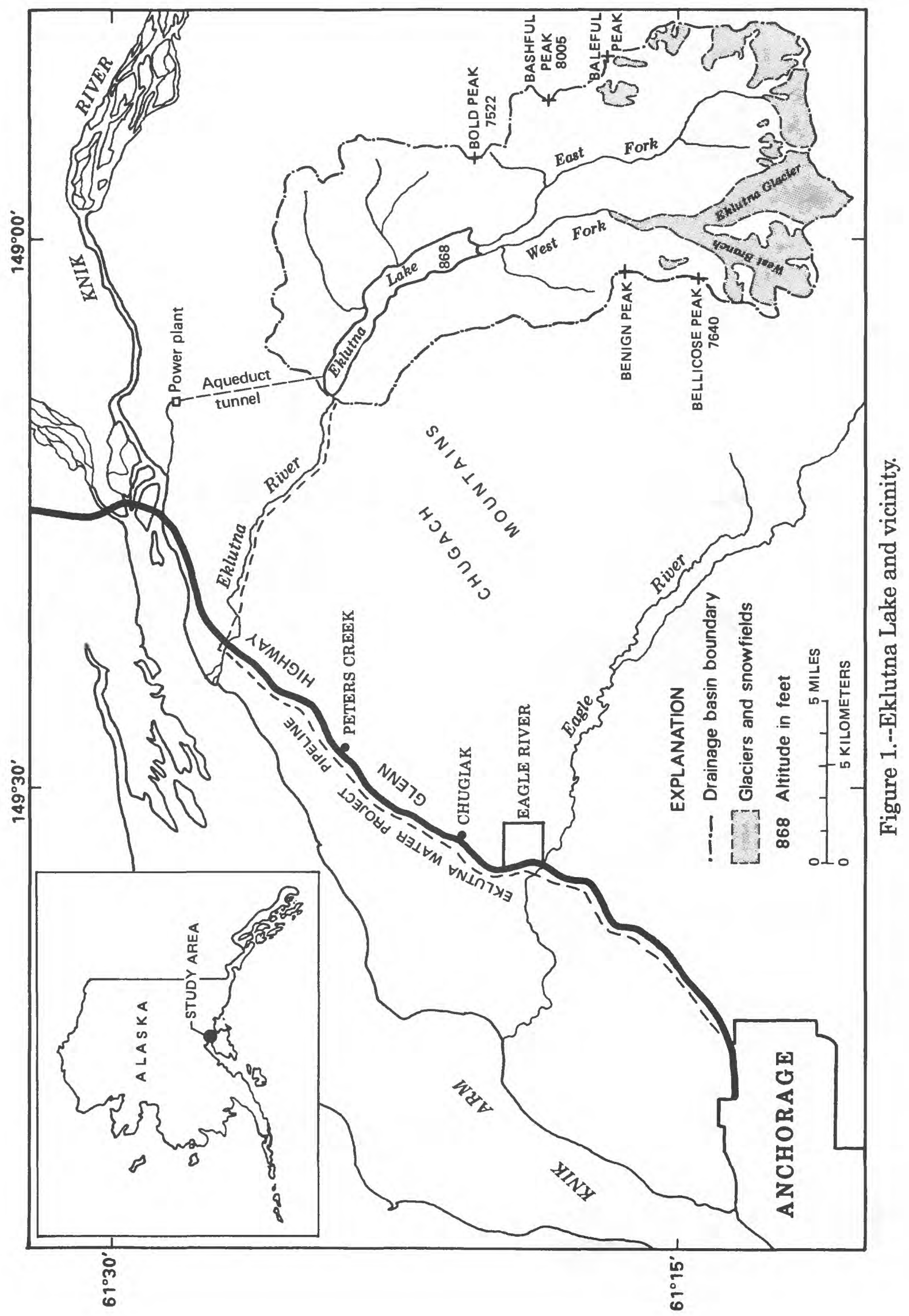


the lake. Precipitation and air temperature data were also collected at these stations to detect climatological differences between the two basins and at different altitudes. Bedload and suspended-sediment data were collected to determine the total quantity of sediment entering Eklutna Lake.

Bathymetric profiles of Eklutna Lake were made to determine lake volume and to locate sediment deposition areas (deltas, channel deposits, areas of uniform sediment deposits). Light-transmissivity profiles were made to identify and delineate density plumes within the lake. Lake levels were monitored at a site (plate 1) (station No. 15278000) and were used in storage analysis. Historical information, such as inflow, lake levels, and water use, was also available from the Eklutna Power Plant and from the Alaska Power Authority (now named the Alaska Energy Authority).

\section{DESCRIPTION OF STUDY AREA}

\section{Watersheds}

The Eklutna Lake drainage basin is approximately $120 \mathrm{mi}^{2}$ in size (plate 1 ). Eklutna Lake (fig. 2) is a long, narrow, deep, glacially formed lake. Near the lower end of the lake, an intake structure and tunnel divert water from the lake to the Alaska Power Administration's Eklutna Power Project and the Municipality's Eklutna Water Project. The lake surface altitude annually ranges from 825 to $870 \mathrm{ft}$ above sea level.

Two watersheds account for more than half of the Eklutna Lake drainage basin. The East Fork Eklutna Creek basin is $38.2 \mathrm{mi}^{2}$ in size, of which approximately 20 percent consists of glaciers (fig. 3). The West Fork Eklutna Creek basin is $25.4 \mathrm{mi}^{2}$ in size, of which about 50 percent consists of glaciers (fig. 3). Numerous small drainages, generally less than $5 \mathrm{mi}^{2}$ in size, constitute the remainder of the Eklutna Lake drainage.

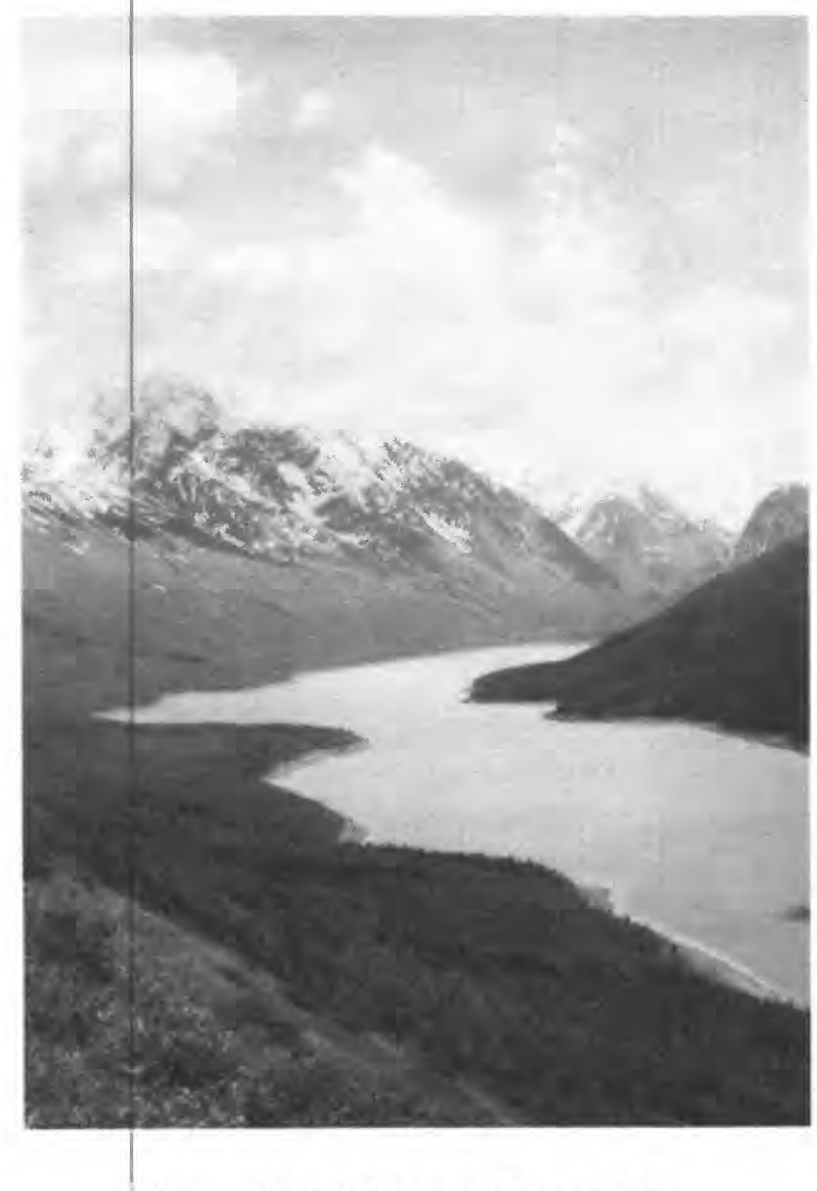

Figure 2.--Eklutna Lake, 1987.

\section{Surficial Geology}

Both the East Fork and West Fork Eklutna basins lie entirely within the Chugach Mountains and are developed primarily in structurally complex and variably metamorphosed sedimẹtary and igneous rock. The topography is rugged and the glaciers are surrounded by cliffs and gullies. Vegetation in the West Fork basin is sparse whereas vegetative cover is somewhat greater in the lower part of the East Fork basin flood plain.

Alluvial deposits, consisting chiefly of gravel and sand, are present at the south end of Eklutna Lake and at the mouths of various tributaries along the lake (plate 1). Colluvial deposits, which have accumulated on slopes primarily through the action of gravity and running water, are present locally along the 


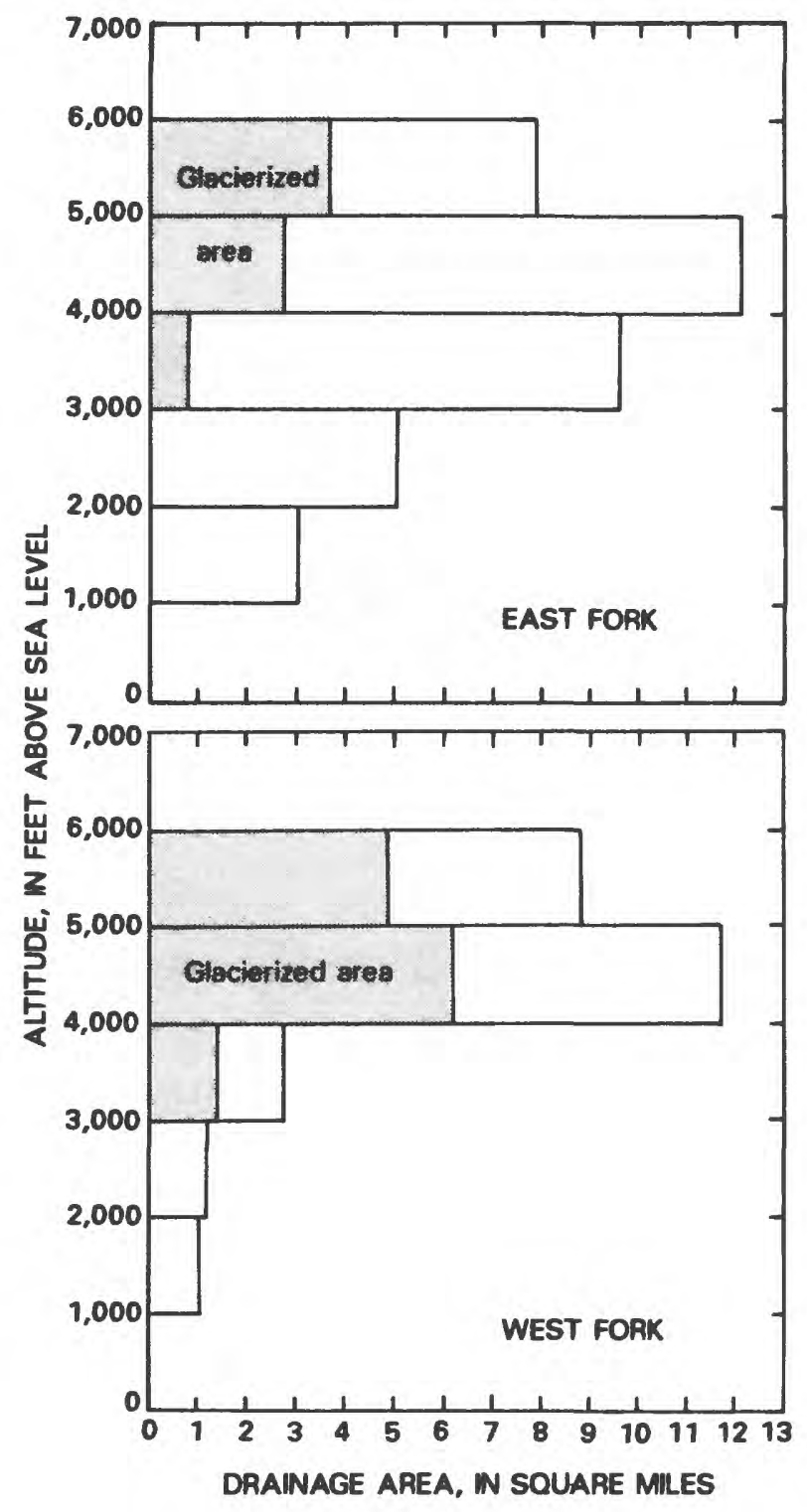

Figure 3.--Area-altitude distribution of the East Fork and West Fork Eklutna Creeks basins.

steep slopes in the East Fork and West Fork Eklutna basins (plate 1). Rock glaciers and their deposits are common in high-level cirques. Thick glacial, glaciolacustrine, and glacioalluvial deposits are found only in the Eklutna River valley downstream from Eklutna Lake.

Because surficial deposits are thin and because impermeable bedrock dominates the basin, ground-water storage in the study area is probably minor. Also, runoff from these basins from rain, snowmelt, or icemelt is expected to be rapid because little or no infiltration would occur.

Surficial geology (plate 1) was mapped between 1965 and 1988, mainly from interpretation of 1:40,000 scale aerial photographs taken in 1957 and by field investigations. Topographic maps that were based on this aerial photography were used to determine the drainage areas and glacier areas of the East and West Fork Eklutna Creeks.

\section{Glaciers}

Glaciers are located in both the East Fork and West Fork Eklutna Creek basins. A series of small, steep glaciers cover about 20 percent of the East Fork basin (fig. 4). These glaciers originate at peaks at about $6,000 \mathrm{ft}$ altitude and terminate at about $3,000 \mathrm{ft}$.

Eklutna Glacier (fig. 5) covers about 50 percent of the West Fork basin. The glacier is currently about $8 \mathrm{mi}$ long; its source is the slopes of peaks at about $6,000 \mathrm{ft}$ altitude. In 1957, the terminus was at about 1,200 ft (Field, 1975); during field observations in 1988, it was at approximately $2,400 \mathrm{ft}$. The terminus has retreated about $1 \mathrm{mi}$ in 30 years. The equilibrium line altitude (ELA) was estimated to be at $4,000 \mathrm{ft}$ in 1957. During the study period, the ELA remained at approximately this same altitude.

\section{Eklutna Lake}

Eklutna Lake occupies an elongated, glacially steepened depression dammed by a recessional terminal moraine of Eklutna Glacier (Karlstrom, 1965). This glacial lake is fed primarily by inflow from the East Fork and West Fork Eklutna Creeks. Two seasons characterize Eklutna Lake: (1) summer, when the lake is ice-free and when most of the water and 


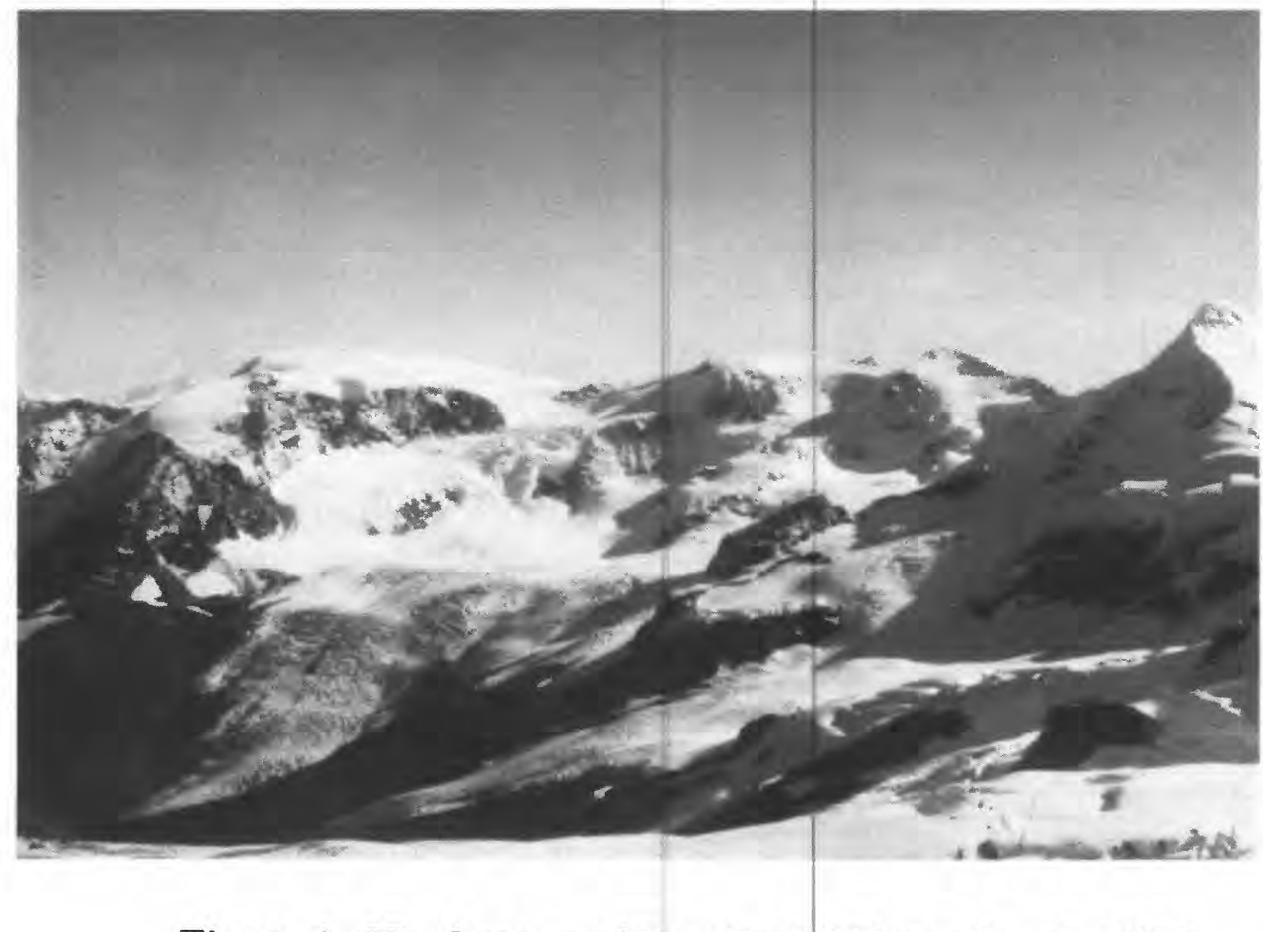

Figure 4.--Headwaters of East Fork Eklutna Creek, 1987.

sediment enter the lake, and (2) winter, when the lake and most of the inflow streams are frozen, when little or no flow enters into the lake, and when the fine sediment particles that are still in the water column slowly sink to the bottom as vertical fallout. The length of the winter season may equal or exceed that of the summer season.

In terms of thermal classification, Eklutna Lake is a dimictic lake. During the summer season, June to September, the lake becomes thermally stratified: warmer water overlies colder water (fig. 6A). As the lake water circulates, the water temperature becomes isothermal from fall to early winter (fig. 6B). Then in winter (late December to early March) the lake becomes inversely stratified: colder water overlies warmer water. In spring, the water becomes isothermal and the process repeats itself.
The morphometry of Eklutna Lake is given on table 1. The lake is long (6.5 mi), narrow $(0.85 \mathrm{mi})$, and deep (average depth, $120 \mathrm{ft}$ ) (fig. 7). The combined flow of the East Fork and West Fork Eklutna Creeks is highly seasonal (fig. 8A) and thus the corresponding lake level has a large annual variation (fig. $8 \mathrm{~B}$ ).

\section{GLACIER MASS BALANCE}

The difference between accumulation and ablation (melting) at a given location on a glacier is called the "ice balance" or "mass balance" at that point (Mayo and others, 1972). If the mass balance averaged over the glacier is positive, the glacier increases mass by storing water. Conversely, if the mass balance averaged over the glacier is negative, the glacier loses mass as meltwater, evaporation, and calving. Mass changes observed on a glacier's surface usually are not immediately reflected in the volume of runoff from the drainage basin, mainly because of the storage characteristics of the glacier. 


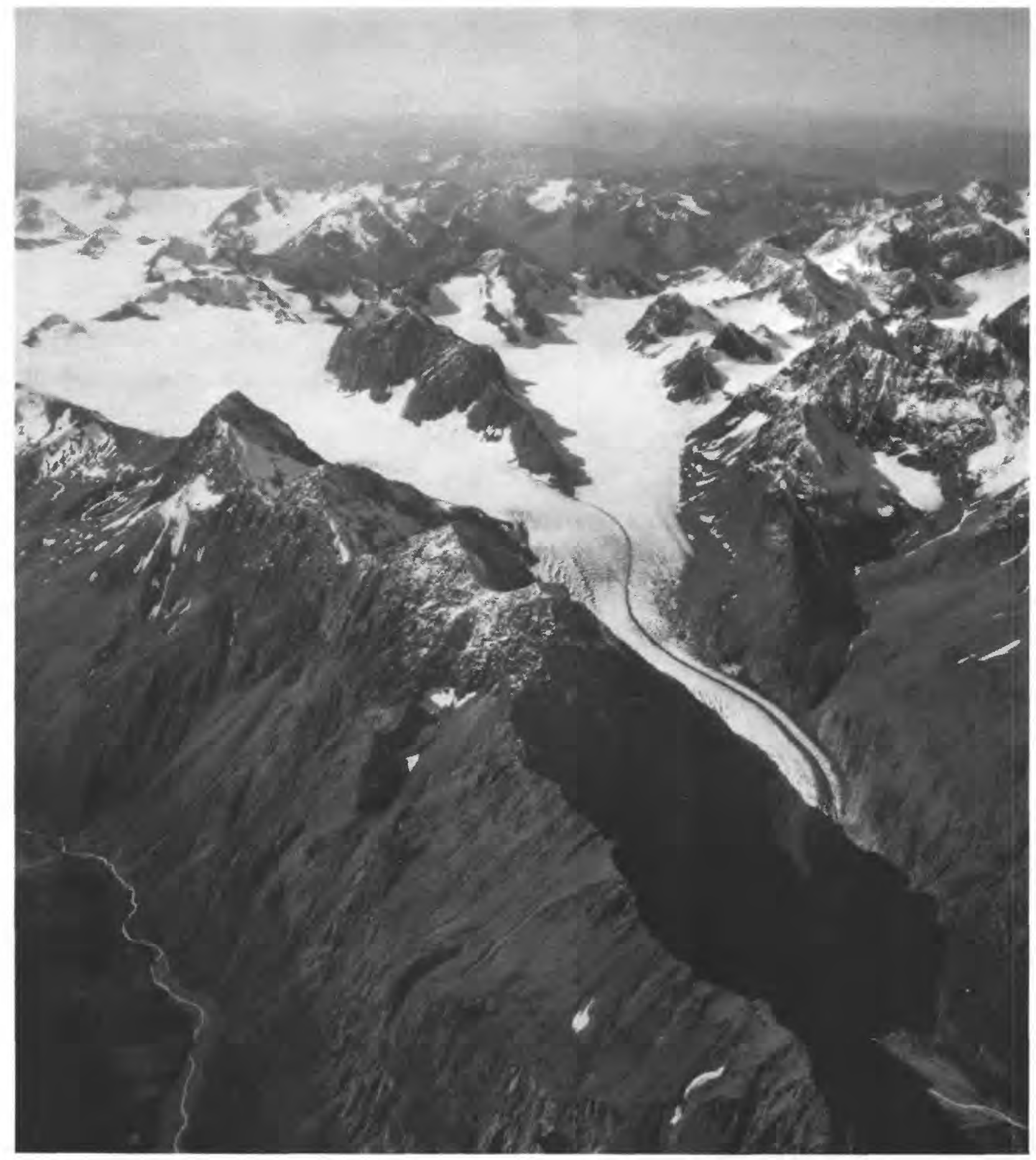

Figure 5.--Eklutna Glacier, 1965. 


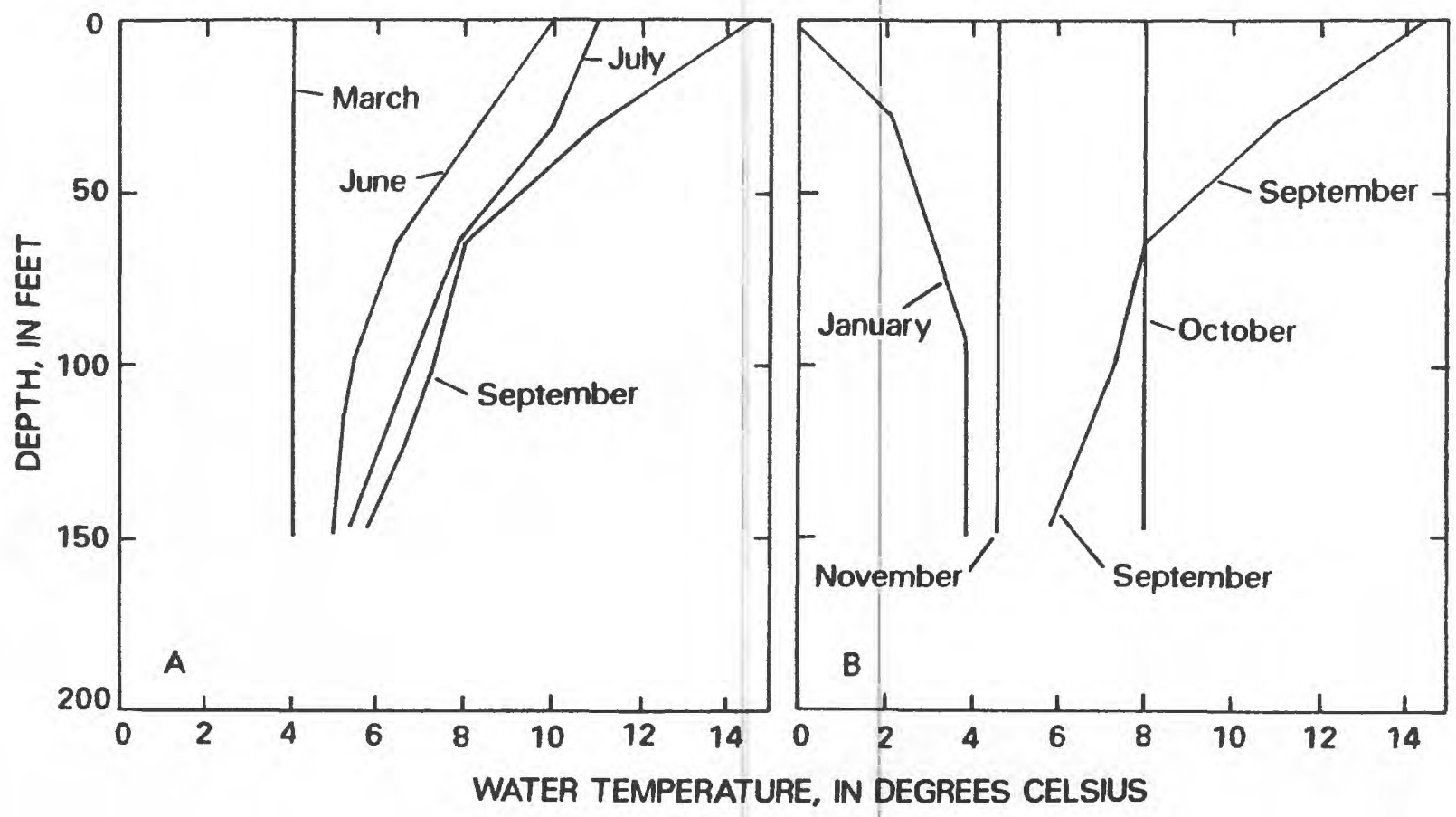

Figure 6.--Water temperature profiles of Eklutna Lake showing: A, summer stratification and $\mathrm{B}$, winter inverse stratification.

Table 1.--Morphometry of Eklutna Lake at 860.00 feet water-surface altitude

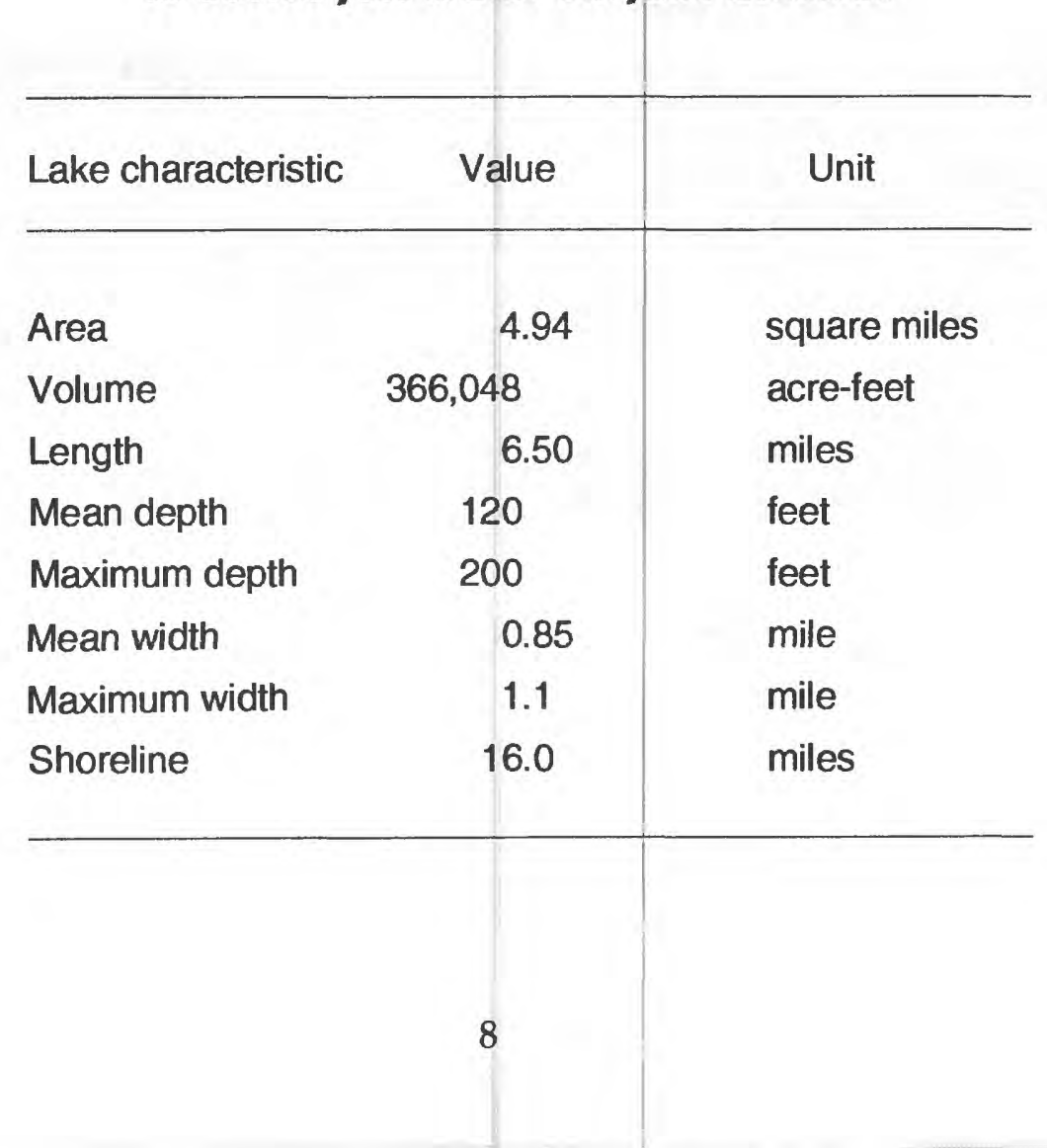




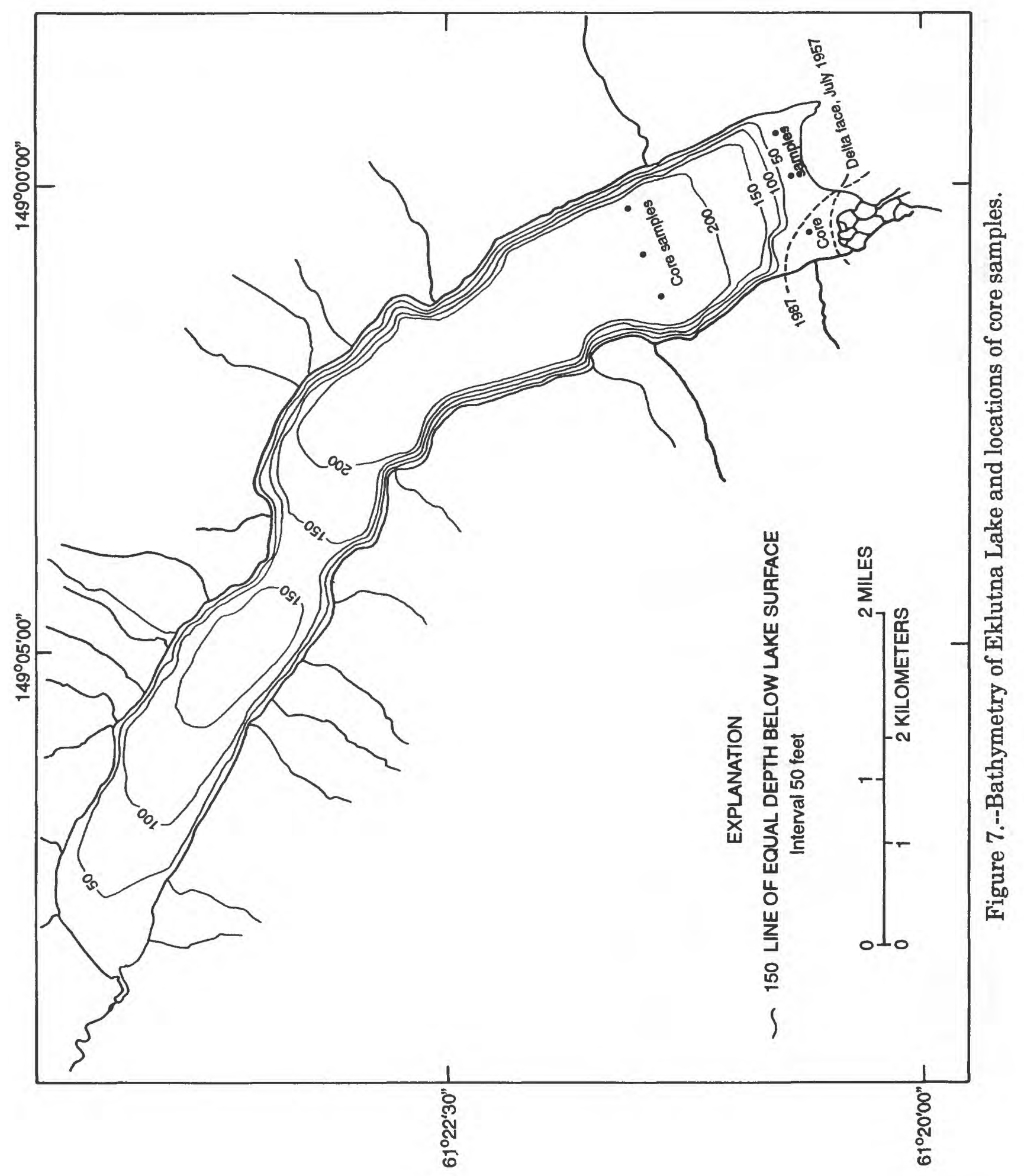




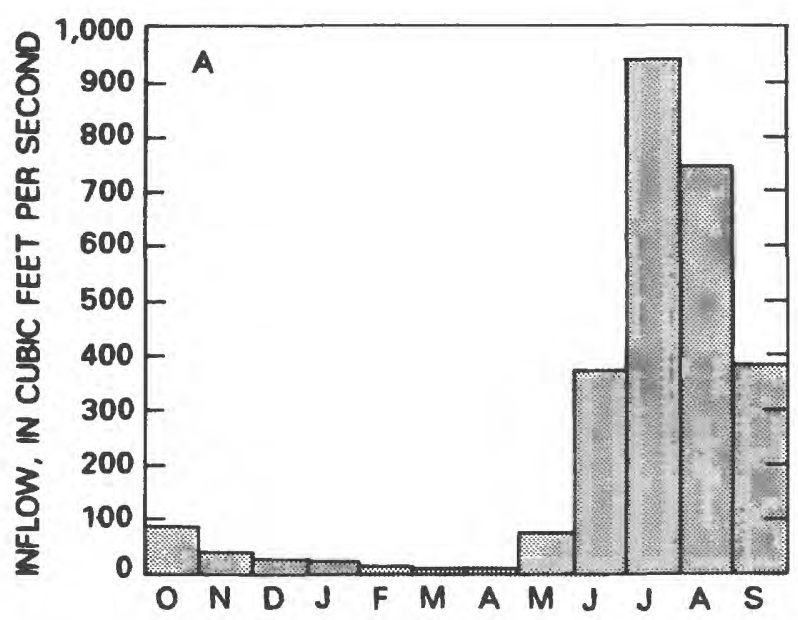

Figure 8.--Characteristics of Eklutna Lake, 1986 water year, showing: A, monthly inflow; and B, monthly lake level.

Accurate measurements of snow accumulation, rainfall, snowmelt, and ice ablation are required to determine the mass balance of a glacier. Although measurements of snowmelt and ice ablation are relatively simple and can be made with a high degree of accuracy, measurements of precipitation are difficult. Thus, in averaging these measurements over the glacier surface to determine the mass balance, some errors will be unavoidable.

For this study, estimates of the errors in mass balance measurements of Eklutna Glacier were made using methods described by Pelto (1988), Meier and others (1971), and Tangborn and others (1977). These authors estimated errors in mass balance for both the accumulation zone and ablation zone on the basis of factors such as variation in snow density, variation in ice density, stake settling, and sampling density. Total errors in mass balance ranged from -0.33 to $0.98 \mathrm{ft}$; a value of $0.6 \mathrm{ft}$ was assumed for this study.

Snow accumulates on Eklutna Glacier and the surrounding glaciers from late September to mid-April. Pits were dug at various altitudes on the glacier and at different times of the year to determine the current year's snow density characteristics (table 2). During the

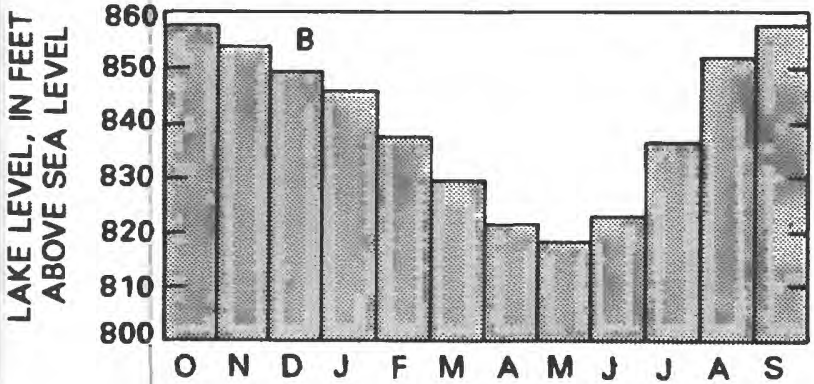

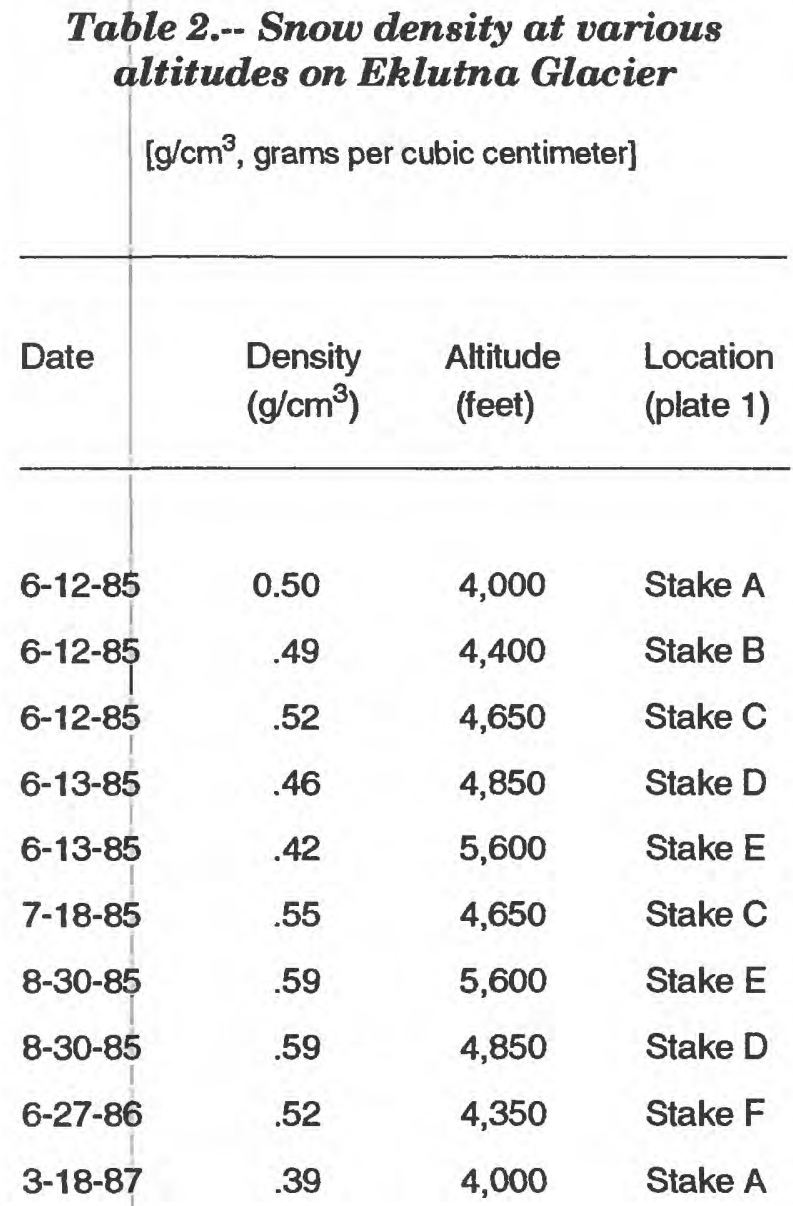


4-year study period, the density did not differ significantly with altitude, but it did differ seasonally. The lowest value of snow density measured was $0.39 \mathrm{~g} / \mathrm{cm}^{3}$, in mid-March. In June, the average density increased to approximately $0.50 \mathrm{~g} / \mathrm{cm}^{3}$, which would be expected because of compaction of the snowpack. In late August, the average density increased to $0.59 \mathrm{~g} / \mathrm{cm}^{3}$.

Accumulation of snow and ablation of ice and snow from Eklutna Glacier were estimated by measurement of stakes placed in the glacier surface (plate 1) and by additional probing of the snowpack. The accumulation/ ablation values obtained at the stakes were then integrated over the entire glacier. No similar measurements were made on the series of small glaciers in the East Fork Eklutna Creek basin. However, because these glaciers are north facing and are at approximately the same altitude as Eklutna Glacier, it was assumed that their accumulation and ablation characteristics would be similar to those of Eklutna Glacier.
On the basis of probing and observations in snow pits, snow accumulation on Eklutna Glacier increases with higher altitude. Averaged over the glacier, snow amounts were similar during the 1985-87 water years (table 3 ). However, the 1988 water year was an exceptional snow year - the average of $100 \mathrm{in}$. water equivalent of the snowpack was almost twice as much in any of the previous 3 years.

The rate of snow ablation was generally equal over the glacier surface from June to mid-July (fig. 9). From mid-July to the end of September, ablation rates appeared to vary with altitude. Ablation of snow and ice for the 4-year study period ranged from $47.0 \mathrm{in}$. to $78.3 \mathrm{in}$. water equivalent for snow and from 5.0 in. to 9.1 in. water equivalent for ice (table 3). The amount of icemelt in 1988 was the lowest measured during the study period and is probably due to the thick snowpack that covered the glacier during that spring.

Table 3.-- Mass balance measurements on Eklutna Glacier, 1985-88

[All values in inches of water equivalent, except accumulation area ratio]

\begin{tabular}{lccccc}
\hline $\begin{array}{l}\text { Water } \\
\text { year }\end{array}$ & $\begin{array}{c}\text { Snow } \\
\text { accumulation }\end{array}$ & $\begin{array}{l}\text { Snow } \\
\text { ablation }\end{array}$ & $\begin{array}{c}\text { Ice } \\
\text { ablation }\end{array}$ & $\begin{array}{c}\text { Net } \\
\text { change }\end{array}$ & $\begin{array}{c}\text { Accumulation } \\
\text { area } \\
\text { ratio }\end{array}$ \\
\hline 1985 & 55.3 & 47.0 & 7.4 & +1.0 & 0.58 \\
1986 & 58.0 & 63.0 & 8.3 & -13.3 & .60 \\
1987 & 54.8 & 54.0 & 9.1 & -8.3 & .60 \\
1988 & 100.0 & 78.3 & 5.0 & +16.7 & .75 \\
\hline
\end{tabular}




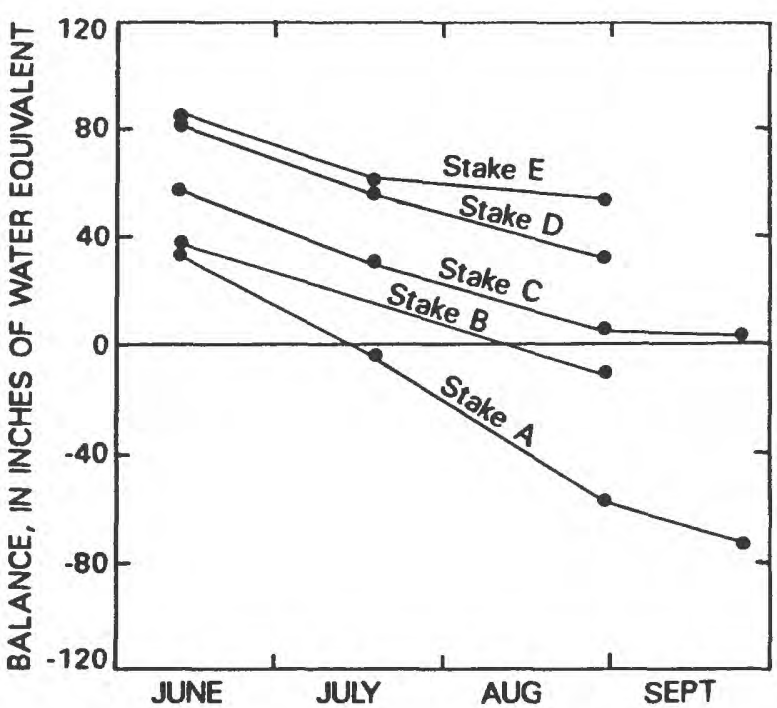

Figure 9.--Ablation of snow and ice on Eklutna Glacier,1985 water year.

In summary, the mass balance calculations of Eklutna Glacier made during the 1985-88 water years, given the errors associated with these calculations, indicate no significant changes to Eklutna Glacier. As an additional check, the accumulation area ratio (area of accumulation/total area), abbreviated AAR, was determined for Eklutna Glacier for the period of study (table 3 ) and ranged from 0.58 to 0.75 . Previous work by Meier and Post (1962) indicated that a land glacier with an AAR between 0.5 and 0.8 is neither advancing nor retreating.

\section{GLACIER RUNOFF}

Glaciers store an enormous amount of water in the form of ice. This feature alone makes any drainage basin containing glaciers both unique and complex. The release of this water is highly dependent on the energy supplied by solar radiation and air temperature (Meier, 1969). A hot summer will cause rapid melting and high runoff, whereas a cool summer will have low runoff.

Runoff from glacier-fed rivers is strongly influenced by the glacier behavior. For example, during a single year, the mass of a glacier may increase, decrease, or remain the same.
When a glacier decreases (negative mass balance), the basin will yield more water than a similar basin without glaciers. A growing glacier stores and thus withholds some water from the normal runoff in the stream. Even if a glacier is in equilibrium, most of the meltwater will be released during a fairly short summer season. The peak runoff from glaciers occurs later than that from lower altitude, non-glacier areas (Meier and Tangborn, 1961).

The extra water withheld by the glaciers may affect the amount of runoff from the basin. For example, Fountain and Tangborn (1985) found that in certain years the water yield from a glacierized basin was 20 to 30 percent higher than the water yield from a nonglacierized basin.

\section{Streamflow Characteristics}

The hydrograph of stream discharge provides a good picture of its flow characteristics. Discharge hydrographs for the East Fork and West Fork Eklutna Creeks (fig. 10) show distinct diurnal fluctuations. The low flow of the day usually occurs in the mid-morning and the high flow occurs in the evening, reflecting the time lag between melting of snow and ice and the arrival of the resulting meltwater at the gaging station.

Annual hydrographs (figs. 11-12) indicate that from about the end of October until April or early May, flows steadily declined in both basins. A noteworthy difference between the two streams is that the East Fork Eklutna Creek is characterized by a ground-water base flow component. During the study period, base flows kept this stream ice-free in winter whereas no flow occurred in West Fork Eklutna Creek. Rising temperatures in May initiate snowmelt and consequent runoff throughout the basins, and near the end of June the melt increases to a maximum. Annual peaks in streamflow occur during July and August when glacial melt and storm runoff coincide. Streamflow declines during September and October as air temperatures cool, and snowmelt and icemelt decrease. Occasional peaks are due to storms in late fall. 


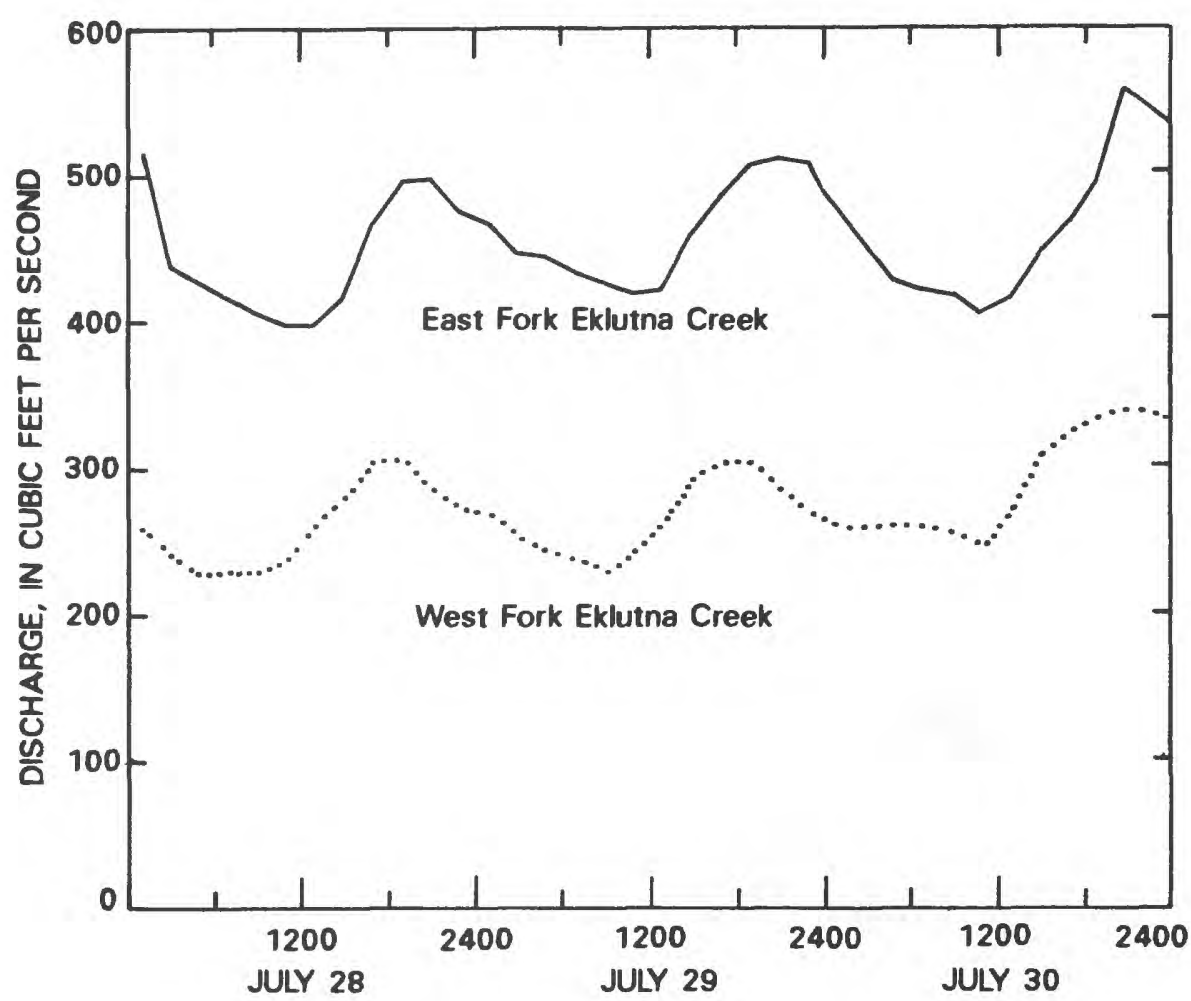

Figure 10.--Streamflow of East Fork and West Fork Eklutna Creeks, July 28-30, 1985.

\section{Runoff Comoonents}

Although the East Fork basin is larger than the West Fork basin, comparison of unit runoff (figs. 13-14) indicates more runoff from the latter basin. During the June-to-September periods of the 4-year study, runoff from the East Fork basin (20 percent glacierized) ranged from 34.13 to 44.28 in., while runoff from the West Fork basin (50 percent glacierized) ranged from 43.34 to $55.79 \mathrm{in}$. Over an entire water year, more than 80 percent of the total runoff in the East Fork basin occurs from June through September, while more than 90 percent of the total runoff in the West Fork basin occurs during these 4 months. During May, runoff from the East Fork accounts for about 5 percent of the total yearly runoff, whereas runoff in the West Fork basin accounts for about 1 percent of the total runoff. The difference in runoff between the two basins during May is probably because snowmelt in the West Fork basin is accumulating in the snowpack or draining through the glacier, instead of becoming immediate runoff.

In water years 1985, 1987, and 1988, Juneto-September runoff from the West Fork basin was approximately $10 \mathrm{in}$. higher than that from the East Fork basin. In water year 1986, runoff was approximately $20 \mathrm{in}$. higher in the West Fork basin than in the East Fork basin. Two possible causes for this significant difference are: (1) the heavy precipitation that was localized on Eklutna Glacier did not occur in the East Fork basin (table 4), and (2) air temperatures in the West Fork basin in July and August average approximately $2{ }^{\circ} \mathrm{F}$ warmer than those in the East Fork basin, which may have caused increased icemelt. 


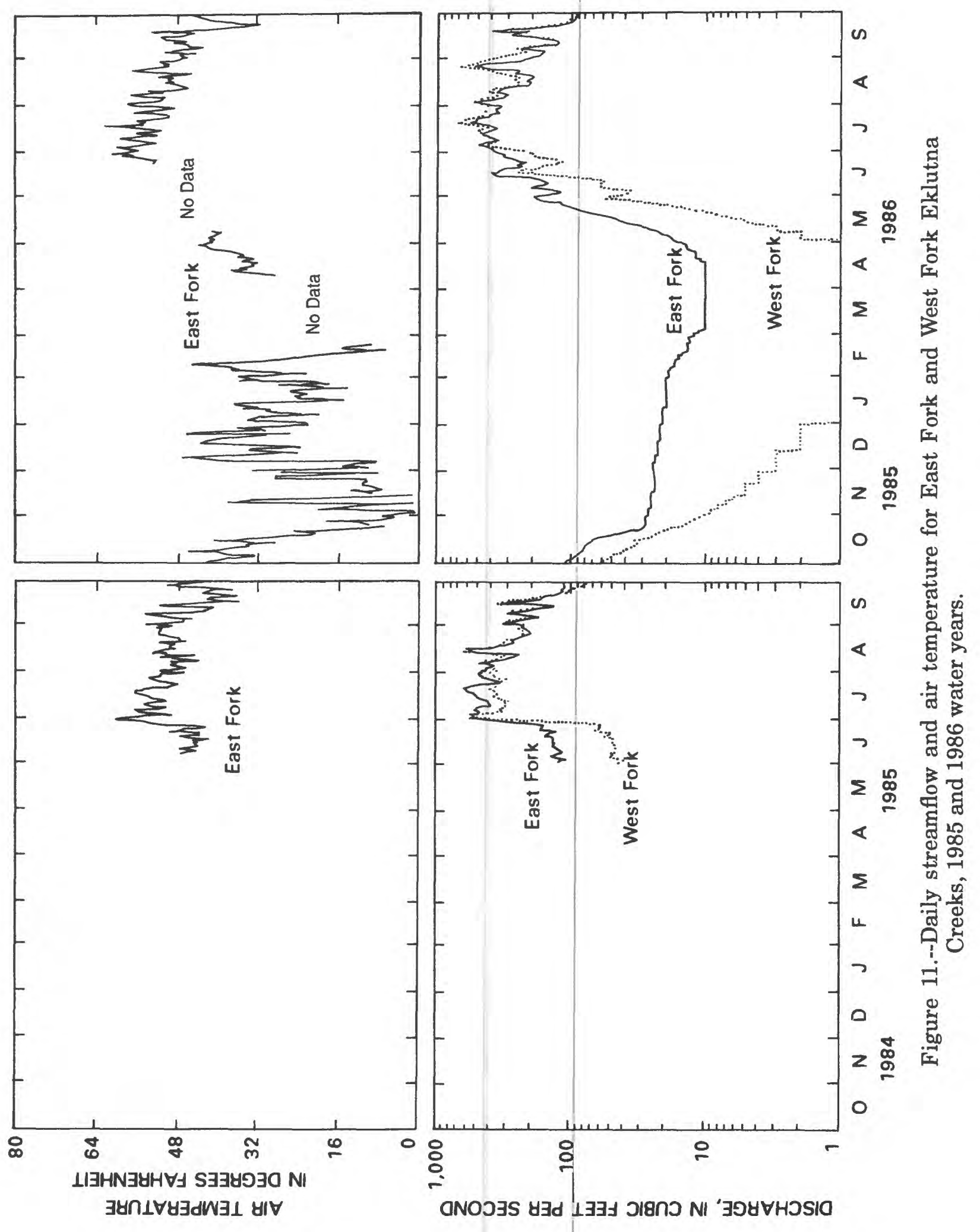




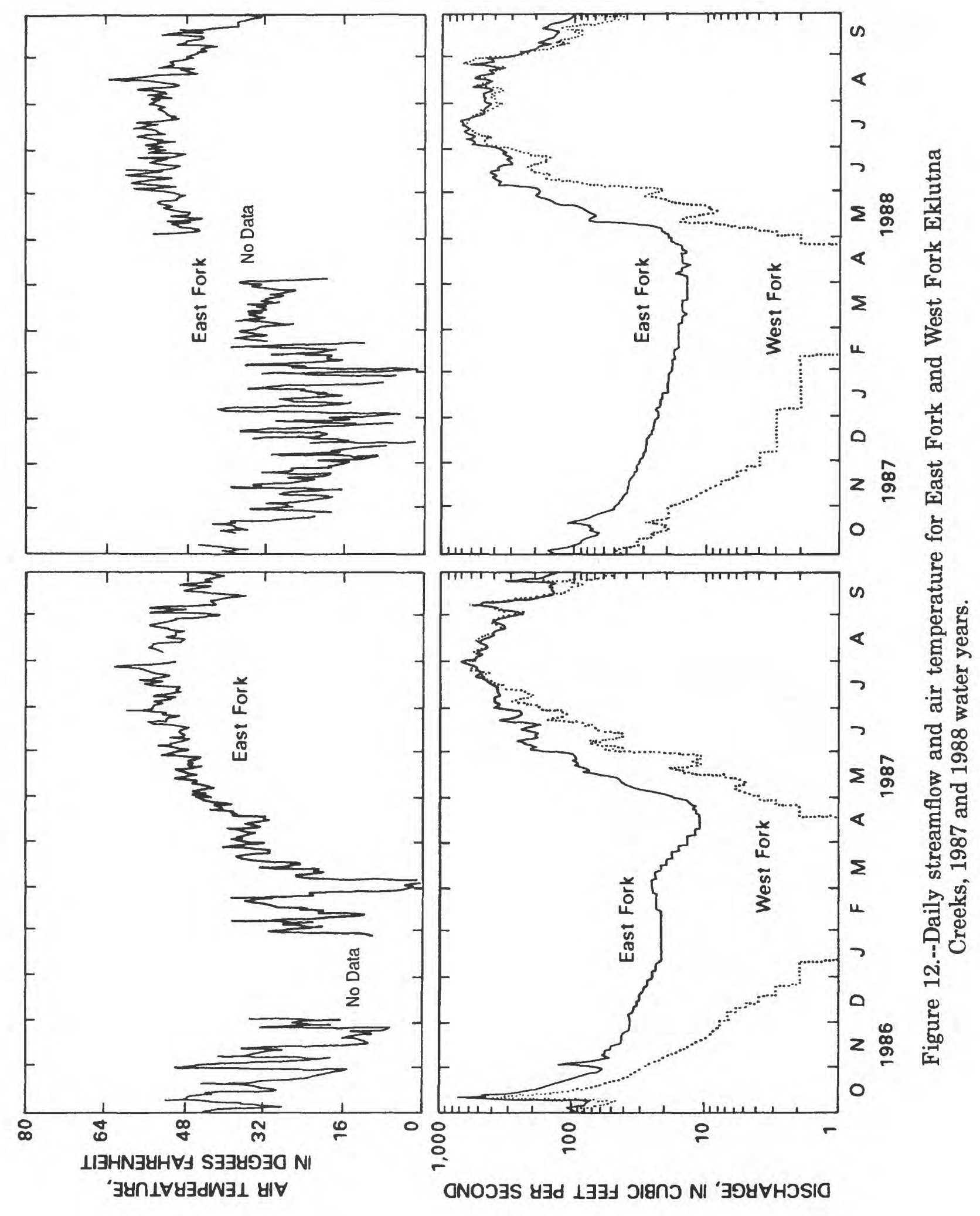




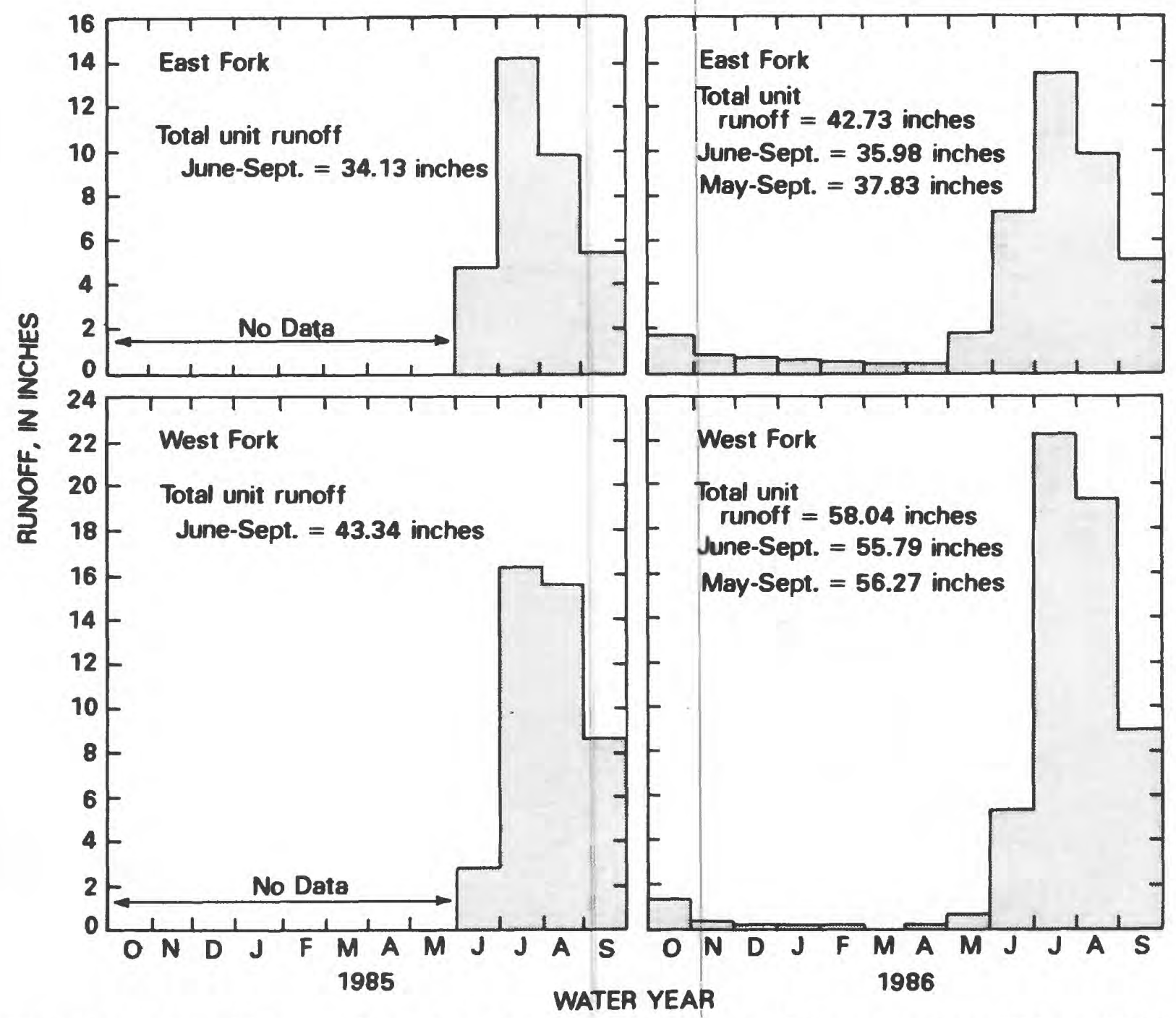

Figure 13.--Monthly runoff for East Fork and West Fork Eklutna Creeks, 1985 and 1986 water years.

The hydrologic balance, which is the difference between inflow (mostly precipitation) and outflow (mostly runoff) was determined for the East Fork and West Fork Eklutna basins for the period June to September. Balances were based on the following assumptions:

1) The discharge measured at the two gaging stations was considered to be the most accurately measured of the variables, which also included icemelt, snowmelt, and rainfall.

2) From analysis of the streamflow discharge for East Fork Eklutna Creek, a ground-water component of 1.6 in. was estimated and used for this station. A ground-water component of $0.0 \mathrm{in}$. was used in balance calculations for West Fork Eklutna Creek.

3) Icemelt for the West Fork basin was assumed to be equal to the icemelt estimated for Eklutna Glacier (table 3). For the glaciers in the East Fork basin, it was assumed that the icemelt characteristics were the same as those for Eklutna Glacier. Thus, the quantity of icemelt was computed by dividing the 


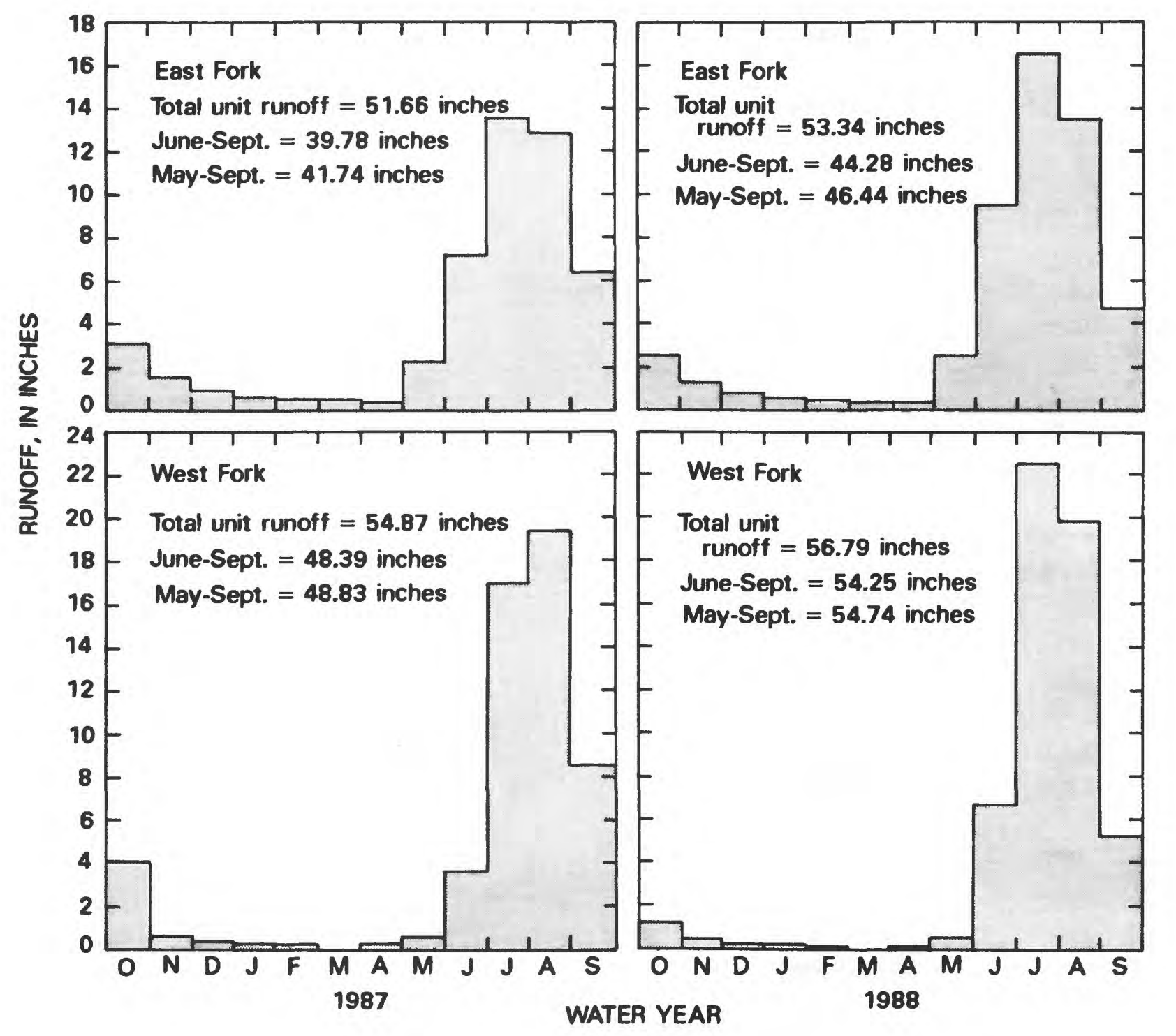

Figure 14.--Monthly runoff for East Fork and West Fork Eklutna Creeks, 1987 and 1988 water years.

area of the glaciers in the East Fork basin below the ELA by the area of Eklutna Glacier below the ELA, and then multiplying this number by the icemelt from Eklutna Glacier. It was assumed that all icemelt from both basins became runoff that was measured as discharge at the corresponding gaging station.

4) Runoff caused by snowmelt and rainfall was assumed to increase with a decrease in altitude (fig. 15).

5) Evaporation losses were assumed to be negligible.

Hydrologic balances of the two basins indicate that glacier icemelt contributes between 9 and 19 percent of the flow in the West Fork basin and between 6 and 13 percent of the flow 
Table 4.-- Precipitation measured in the Eklutna Lake basin, 1985-88

[Number below site name is altitude in feet above sea level; all table values are in inches; ---, no data available]

\begin{tabular}{|c|c|c|c|c|}
\hline \multirow{2}{*}{$\begin{array}{l}\text { Year } \\
\text { and } \\
\text { month }\end{array}$} & \multicolumn{2}{|c|}{ Eklutna Creek } & \multirow{2}{*}{$\begin{array}{l}\text { Eklutna } \\
\text { Glacier } \\
(4,000)\end{array}$} & \multirow{2}{*}{$\begin{array}{l}\text { Eklutna } \\
\text { Power Plant } \\
\text { (350) }\end{array}$} \\
\hline & $\begin{array}{c}\text { East Fork } \\
(1,050)\end{array}$ & $\begin{array}{c}\text { West Fork } \\
(1,050)\end{array}$ & & \\
\hline \multicolumn{5}{|l|}{1985} \\
\hline June & --- & -.. & -.. & 1.15 \\
\hline July & 0.08 & 0.26 & 0.82 & .98 \\
\hline August & .61 & --- & 4.11 & 3.57 \\
\hline September & 2.29 & 3.00 & 4.07 & 4.22 \\
\hline \multicolumn{5}{|l|}{1986} \\
\hline June & --- & -- & --- & .76 \\
\hline July & 1.64 & 2.28 & 6.02 & 3.85 \\
\hline August & 1.19 & 1.93 & 6.20 & 2.33 \\
\hline September & 1.10 & 2.61 & 5.96 & 3.46 \\
\hline \multicolumn{5}{|l|}{1987} \\
\hline June & .77 & 1.21 & -- & 2.13 \\
\hline July & 1.92 & 2.04 & 3.72 & 1.34 \\
\hline August & 1.78 & 1.75 & 2.40 & 2.40 \\
\hline September & 2.88 & 4.87 & 8.20 & 2.70 \\
\hline \multicolumn{5}{|l|}{1988} \\
\hline June & .78 & 1.04 & .97 & 2.61 \\
\hline July & .67 & 1.33 & .86 & 2.08 \\
\hline August & 1.45 & 2.11 & 7.54 & 2.53 \\
\hline September & .96 & 2.33 & --- & 2.01 \\
\hline
\end{tabular}




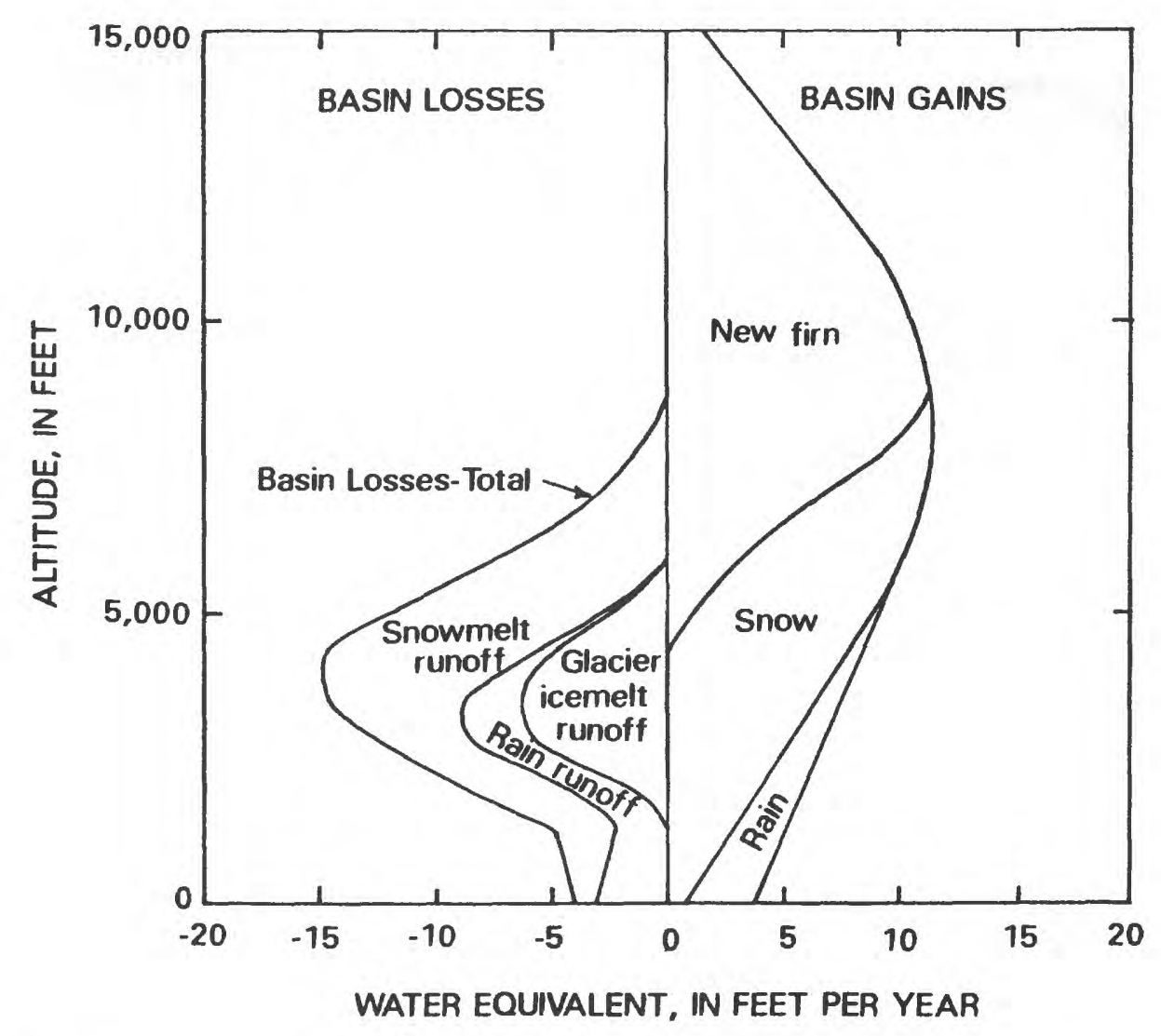

Figure 15.--Altitude distribution of precipitation as rain and snow, accumulation, icemelt, snowmelt, and runoff for a glacier in southcentral Alaska (modified from Mayo and Trabant, 1979).

in the East Fork basin (table 5). Snowmelt and rainfall account for most of the runoff in both basins. Although the estimate for icemelt runoff is considered to be fairly accurate, the estimates for snowmelt and rainfall runoff are considered to bequite variable. The reasons for this variability are: (1) the lack of detailed snowmelt and rainfall data for both basins and (2) the difficulty in determining the quantity of snowmelt and rainfall that actually becomes runoff.

\section{Runoff Prediction}

Methods of predicting runoff from glacierized basins range from simple to complex. The simplest models relate snowmelt to air temper- ature: the most commonly used index is mean daily air temperature in excess of $32{ }^{\circ} \mathrm{F}$. The temperature index method (Anderson, 1973) has the advantage that few data are needed. However, this method does not account for the increasing density of the snowpack or the decrease in the snow-surface albedo as the melt season progresses and it assumes that all snowmelt becomes runoff. More complex models incorporate detailed energy balances and internal flow routing through the glacier. However, internal glacier drainage is poorly understood and experimental verification of internal drainage theories is difficult (Young, 1985). Despite these limitations, two methods (one simple, one complex) were tested to determine their applicability in this study. 
Table 5.-- Estimated distribution of unit runoff of the West Fork and East Fork Eklutna Creeks, June to September, 1985-88

\begin{tabular}{|c|c|c|c|c|}
\hline \multirow{2}{*}{$\begin{array}{l}\text { Water year } \\
\text { and } \\
\text { component }\end{array}$} & \multicolumn{2}{|c|}{ West Fork } & \multicolumn{2}{|c|}{ East Fork } \\
\hline & $\begin{array}{l}\text { Unit runoff } \\
\text { (inches) }\end{array}$ & $\begin{array}{l}\text { Percent } \\
\text { of total }\end{array}$ & $\begin{array}{l}\text { Unit runoff } \\
\text { (inches) }\end{array}$ & $\begin{array}{l}\text { Percent } \\
\text { of total }\end{array}$ \\
\hline \multicolumn{5}{|l|}{1985} \\
\hline Icemelt & 7.4 & 17 & 4.1 & 12 \\
\hline Snowmelt & 24.3 & 56 & 19.0 & 56 \\
\hline Rainfall & 11.6 & 27 & 9.2 & 27 \\
\hline Ground water & 0.0 & 0 & 1.6 & 5 \\
\hline Total & 43.3 & & 33.9 & \\
\hline \multicolumn{5}{|l|}{1986} \\
\hline Icemelt & 8.3 & 15 & 4.6 & 13 \\
\hline Snowmelt & 29.0 & 52 & 19.2 & 53 \\
\hline Rainfall & 18.5 & 33 & 10.6 & 29 \\
\hline Ground water & 0.0 & 0 & 1.6 & 5 \\
\hline Total & 55.8 & & 36.0 & \\
\hline \multicolumn{5}{|l|}{1987} \\
\hline Icemelt & 9.1 & 19 & 5.1 & 13 \\
\hline Snowmelt & 25.2 & 52 & 21.6 & 54 \\
\hline Rainfall & 14.0 & 29 & 11.5 & 29 \\
\hline Ground water & 0.0 & 0 & 1.6 & 4 \\
\hline Total & 48.3 & & 39.8 & \\
\hline \multicolumn{5}{|l|}{1988} \\
\hline Icemelt & 5.0 & 9 & 2.8 & 6 \\
\hline Snowmelt & 34.5 & 64 & 27.9 & 63 \\
\hline Rainfall & 14.7 & 27 & 12.0 & 27 \\
\hline Ground water & 0.0 & 0 & 1.6 & 4 \\
\hline Total & 54.2 & & 44.3 & \\
\hline
\end{tabular}




\section{Statistical Relations}

Statistical regression techniques were used to estimate daily discharge for June 1 to September 30 by using the log-transformed daily discharge, air temperature, and rainfall data collected in the East Fork Eklutna and West Fork Eklutna basins. The regression analysis produced the following equations:

East Fork Eklutna Creek:

$$
\mathrm{EFQ}=33.9(\mathrm{HDD})^{.86}(1+\mathrm{PRECIP})^{.074}
$$

Number of observations $=248$

Coefficient of determination $=.49$

Standard error of estimate (percent) $=40$

West Fork Eklutna Creek:

$$
\left.\mathrm{WFQ}=22.4(\mathrm{HDD}){ }^{96}(1+\mathrm{PRECIP})\right)^{040}
$$

Number of observations $=248$

Coefficient of determination $=.49$

Standard error of estimate (percent) $=45$

where $\quad E F Q$ is daily discharge for East Fork Eklutna Creek, in cubic feet per second;

WFQ is daily discharge for West Fork Eklutna Creek, in cubic feet per second;

HDD is heating degree days (equals average temperature for the day minus $32{ }^{\circ} \mathrm{F}$ ); and

PRECIP is precipitation, in inches.

The relatively low coefficient of determination, high standard error of estimate for these two equations, and inspection of figures 16 and 17 indicate that this method would not give reliable results. This is due to the fact that the equations are attempting to describe a fairly complex hydrologic system.

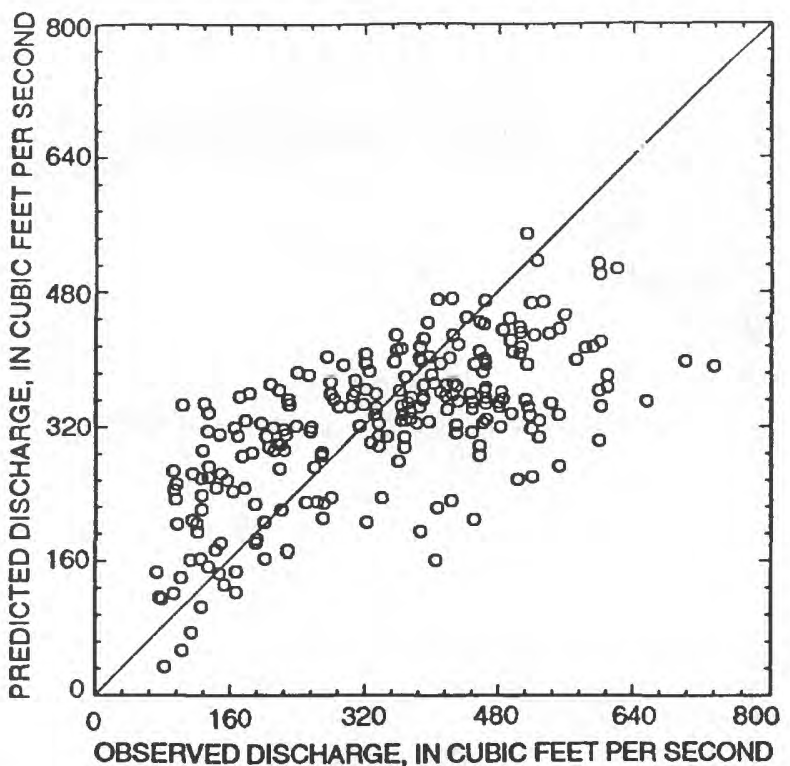

Figure 16.--Observed daily mean streamflow and daily mean streamflow predicted from statistical equations, June to September 1985-88, East Fork Eklutna Creek.

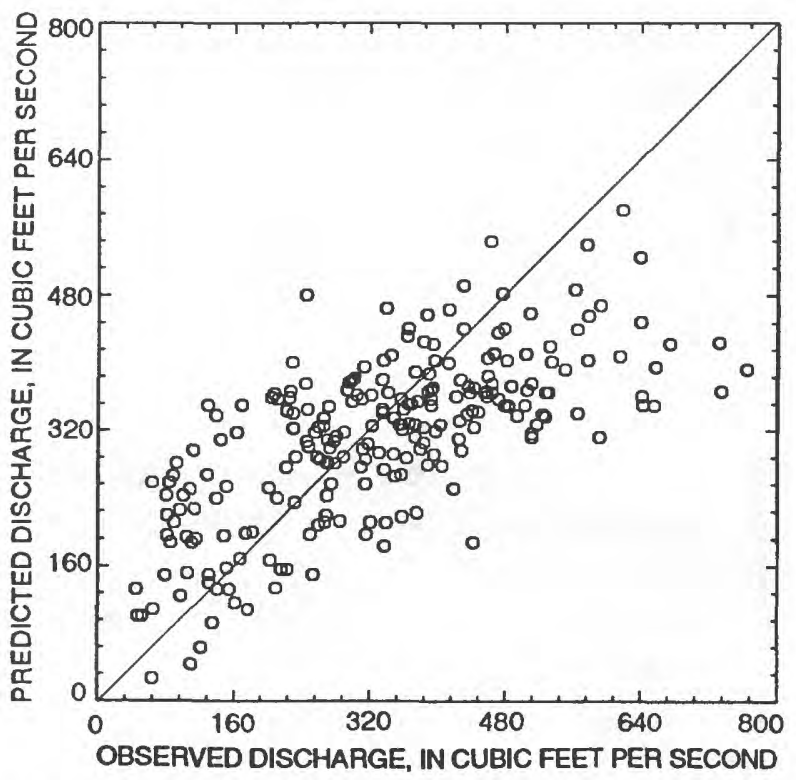

Figure 17.--Observed daily mean streamflow and daily mean streamflow predicted from statistical equations, June to September 1985-88, West Fork Eklutna Creek. 


\section{Precipitation-Runoff Modeling System}

The Precipitation-Runoff Modeling System (PRMS) was developed to evaluate the effects of various combinations of precipitation, climate, and land uses on surface-water runoff (Leavesley and others, 1983). The concept of PRMS is to partition a watershed into units-referred to as hydrologic response units (HRU's)--on the basis of similar characteristics such as slope, aspect, vegetation type, soil type, and precipitation distribution. Thus, for this application, PRMS would enable one to partition the glaciers in the East Fork and West Fork basins into the ablation and accumulation zones, modify the water equivalent of the snowpack using the snow density data collected, and adjust for the differences in precipitation (both snow and rain) with altitude. Temporal changes in watershed characteristics can also be modeled.

Input variables required to run PRMS are physical and hydrologic data for each HRU of the watershed, daily precipitation, maximum and minimum daily air temperature, and daily solar radiation. Using the input data, PRMS simulates processes such as evapotranspiration, snowmelt, and runoff on a daily basis.

Some limitations in applying PRMS to this study were: (1) it does not account for the internal drainage system of a glacier; (2) it does not have a mechanism to account for the enlarging ablation zone during the summer months; and (3) it does not simulate icemelt. However, a very simplified technique was used to determine icemelt and is outlined as follows using certain output variables from PRMS (Leavesley and others, 1983).
1) Determine the net shortwave radiation:

$$
\text { SWN }=S W R D *(1.0-A L B) * T R N C F \text {, }
$$

where SWRD is the computed shortwave radiation received (langleys);

ALB is the albedo of the ice surface, assumed to be 0.4 ; and

TRNCF is the transmission coefficient for the vegetation canopy over the snowpack, assumed to be 1.0.

2) Determine the net longwave radiation:

LWN $=(1.0-\text { COVDNW })^{*}\left[\left(\mathrm{EMIS}^{*} \mathrm{AIRN}\right)-\mathrm{SNON}\right]+$ COVDNW*(AIRN - SNON),

where COVDNW is the winter cover density of the predominant vegetation above the snowpack, assumed to be 0.0;

EMIS is the emissivity of air, assumed to be 0.76 ;

AIRN is the longwave energy emitted from a perfect black body at the average air temperature for the 12-hour period (cal); and

SNON is the longwave energy emitted from the snowpack surface at the surface temperature for the 12-hour period (cal).

AIRN and SNON are computed using the Stefan-Boltzmann law (Leavesley and others, 1983, p. 43). 
3) Determine the latent and sensible heat:

$$
\mathrm{CEN}=\mathrm{CECN}(\mathrm{MO}) * \mathrm{TAVC},
$$

where CECN(MO) is a parameter for month $\mathrm{MO}$, assumed to be 10; and TAVC is the mean air temperature for the 12-hour period (C).

The total energy balance CALN is then

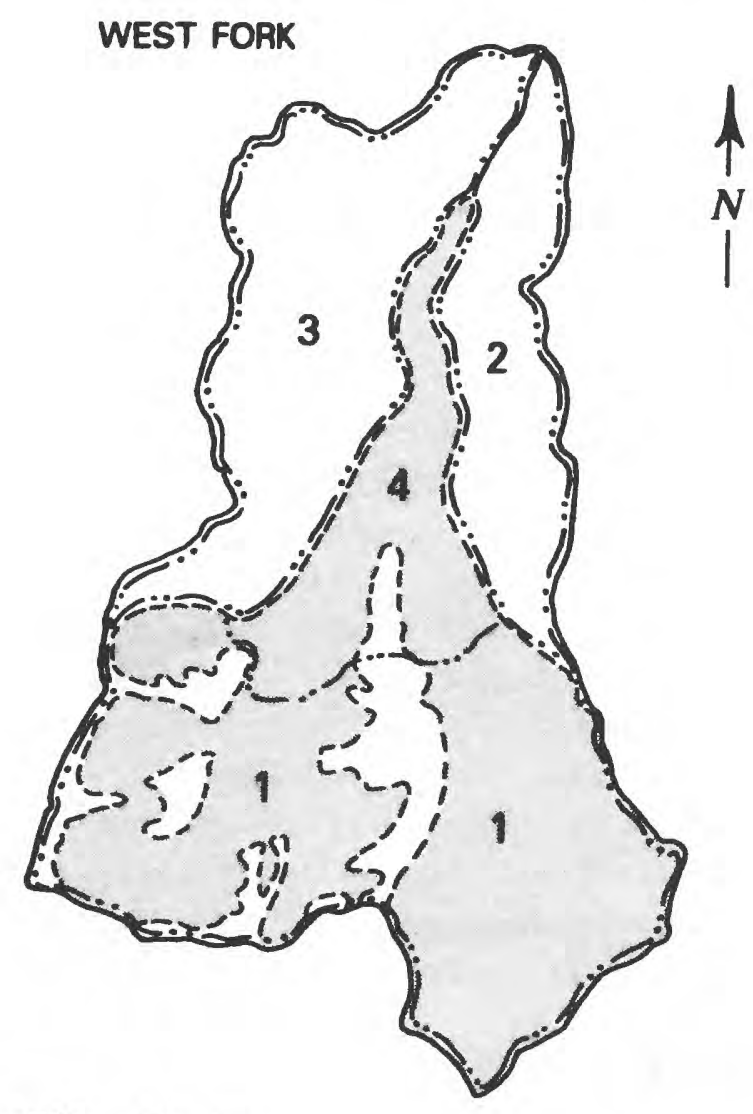

..., Glacier

Hydrologic response unit boundary determined by summing SWN, LWN, and CEN. Icemelt is then computed by CALN/203.2, where 203.2 is the number of calories required to melt $1 \mathrm{in}$. of water-equivalent ice at $0{ }^{\circ} \mathrm{C}$. The total icemelt for the glacier areas was then determined by integrating the value of daily icemelt over the ablation area. Because PRMS does not account for an increasing ablation zone, an average value was used.

The East Fork and West Fork basins were delineated into their respective HRU's (fig. 18).

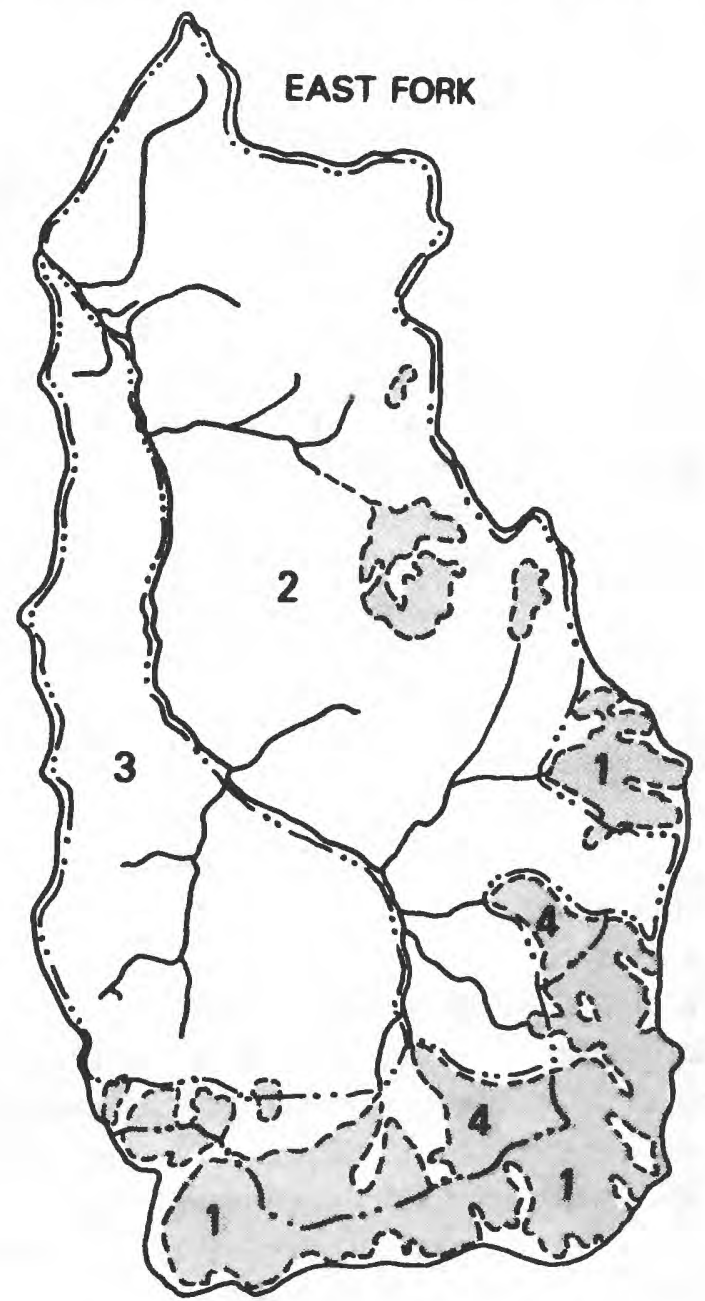

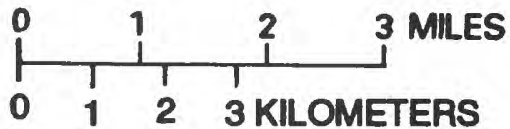

Figure 18.--West Fork and East Fork Eklutna Creek basins partitioned into hydrologic response units. 
Using streamflow, climatological, and physical characteristics of the basins as input, initial runs of PRMS were made. The values of the physical properties were based on typical values outlined by Leavesley and others (1983) and on general hydrologic knowledge of the these two basins. As expected, changes in soil moisture or ground-water properties did not have any significant effect in model output. Output was most sensitive to changes in temperature lapse rates and in precipitation coefficients. Thus, for the remaining simulations, these values were adjusted within reasonable limits until the best fit between observed and simulated discharge was reached. A rigorous calibration and sensitivity analysis was not done because of the previously mentioned limitations of the PRMS in simulating runoff from glacierized basins.

No attempt was made to calibrate observed and simulated discharge for the 1985 water year because of the computational procedures of PRMS and the beginning of the data set (June 1, 1985). The period of icemelt was based on stake ablation data. For 1986 and 1987 , the icemelt period lasted from July 1 to September 1, while in 1988 it lasted from July 20 to September 1.

Daily discharges predicted by PRMS (figs. 19-20) generally follow the trends of the observed discharges for the East Fork and West Fork Eklutna Creeks. Simulated peak discharges are sharper and higher and occur sooner than the observed peak discharges. These features are most likely because PRMS does not account for the internal drainage of glaciers. In general, agreement between observed and simulated daily discharge is closer for West Fork than for East Fork Eklutna Creek. This is probably because the West Fork basin includes Eklutna Glacier and bedrock and is not difficult to partition into HRU's. The larger East Fork basin includes several small glaciers and has some ground-water flow, making it more difficult to partition.

The quantity of icemelt simulated by PRMS agrees reasonably well with the calculated quantity for both the East Fork and West Fork Eklutna basins (table 6). This indicates that the previously mentioned equations for determining icemelt are reasonable. Comparing the observed and simulated discharges on an average monthly basis (table 7) indicates that the differences in simulated and observed values are smaller for June and September, when glaciers are normally not producing any water, than for July and August, when glaciers release most of their water from storage. PRMS underpredicts the quantity of runoff, even after accounting for the icemelt, for July and August (table 7).

Limitations apply to both methods tested for predicting runoff. However, although it is more complex, it is believed that PRMS is a more accurate method for simulating runoff from glacierized basins. Its ability to partition a watershed into distinct units, to distribute precipitation on the basis of altitude, and to account for changes in snowpack allows an accurate description of a watershed in mathematical terms. For PRMS to simulate runoff from glacierized basins still more accurately, more development of the model is needed in representing the storage and release of water from a glacier's internal drainage system.

\section{SEDIMENT TRANSPORT AND DEPOSITION}

The transport of material eroded from a streambank or along the streambed depends on several factors. The streamflow velocity of bed slope usually determines the size and quantity of material transported. These variables change throughout the course of the stream so that uneven beds can form as a result of scour in one part of the stream and deposition in another part. 


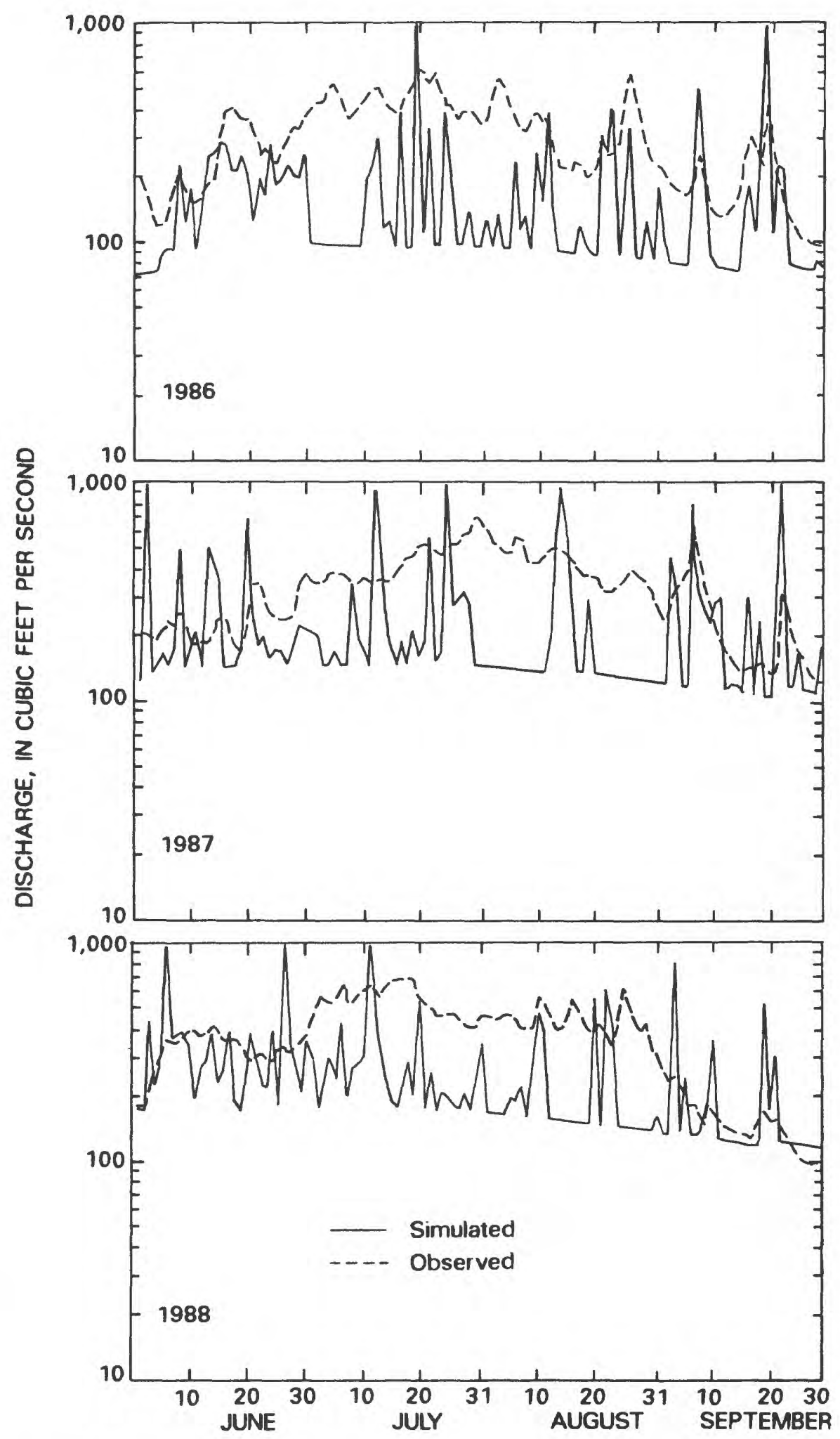

Figure 19.--Observed daily mean streamflow and daily mean streamflow simulated from the PRMS, June to September 1986-88, East Fork Eklutna Creek. 


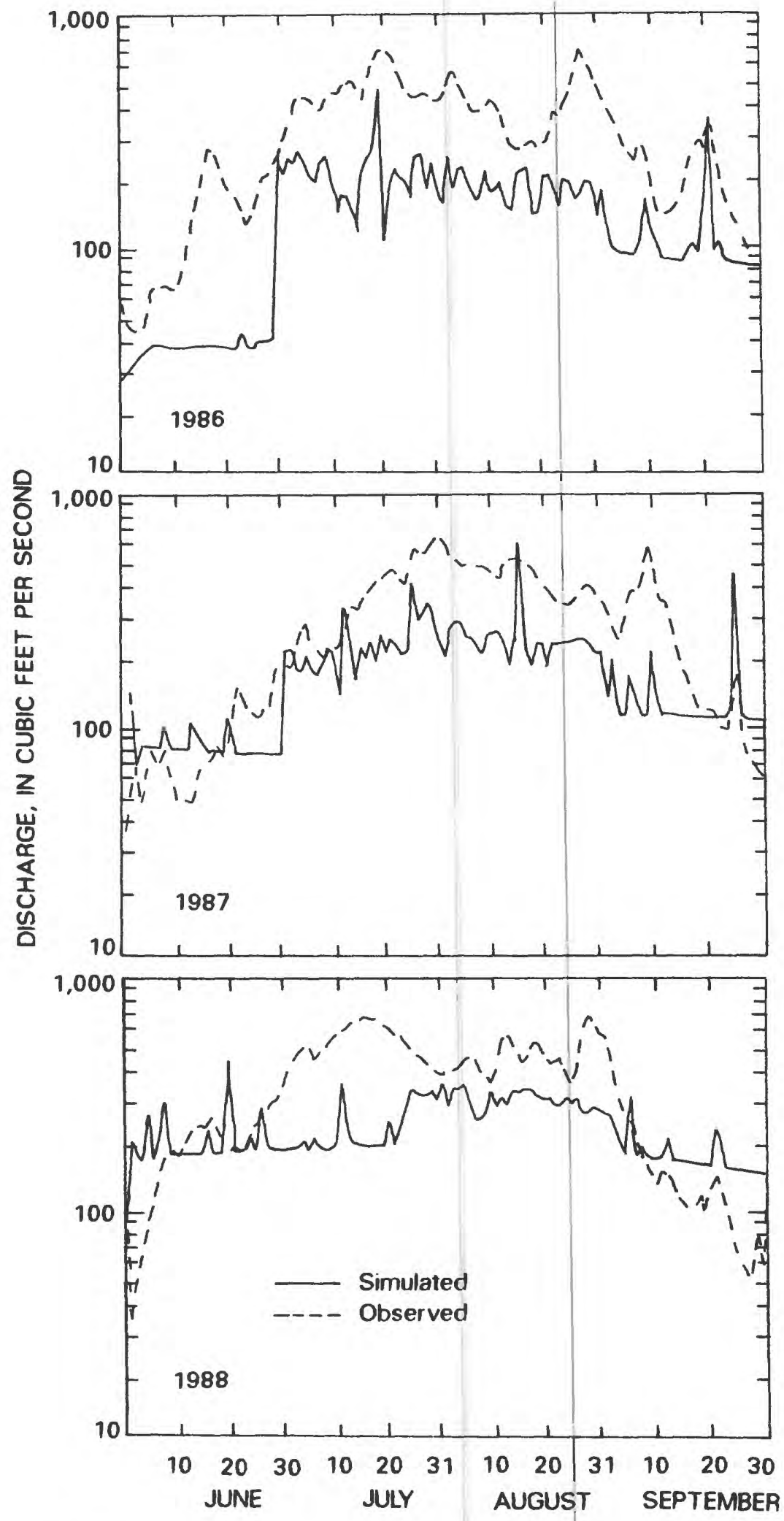

Figure 20.--Observed daily mean streamflow and daily mean streamflow simulated from the PRMS, June to September 1986-88, West Fork Eklutna Creek. 
Table 6.-- Calculated and simulated icemelt for East Fork and West

Fork Eklutna Creeks, June to September, 1986-88

[Values in inches; PRMS, Precipitation-Runoff Modeling System]

\begin{tabular}{lccccc}
\hline \multirow{2}{*}{ Water year } & \multicolumn{2}{c}{ East Fork icemelt } & & \multicolumn{2}{c}{ West Fork icemelt } \\
\cline { 2 - 3 } \cline { 5 - 6 } $\begin{array}{c}\text { Calculated } \\
\text { (table 5) }\end{array}$ & $\begin{array}{c}\text { Simulated } \\
\text { (PRMS) }\end{array}$ & & $\begin{array}{c}\text { Calculated } \\
\text { (table 5) }\end{array}$ & $\begin{array}{c}\text { Simulated } \\
\text { (PRMS) }\end{array}$ \\
\hline 1986 & 4.6 & 4.5 & & 8.3 & 9.5 \\
1987 & 5.1 & 4.4 & & 9.1 & 10.5 \\
1988 & 2.8 & 1.9 & & 5.0 & 5.5 \\
\hline
\end{tabular}

Table 7.-- Observed and simulated average monthly discharges for East Fork and West Fork Eklutna Creeks, June to September 1986-88

[Values in cubic feet per second]

\begin{tabular}{|c|c|c|c|c|c|c|}
\hline \multicolumn{7}{|l|}{ Year } \\
\hline \multirow{2}{*}{$\begin{array}{l}\text { and } \\
\text { month }\end{array}$} & \multicolumn{3}{|c|}{ East Fork discharge } & \multicolumn{3}{|c|}{ West Fork discharge } \\
\hline & Observed & Simulated & Difference & Observed & Simulated & Difference \\
\hline \multicolumn{7}{|l|}{1986} \\
\hline June & 248 & 176 & +72 & 123 & 35 & +88 \\
\hline July & 451 & 264 & +187 & 490 & 224 & +266 \\
\hline August & 327 & 203 & +124 & 422 & 180 & +242 \\
\hline September & 180 & 178 & +2 & 204 & 118 & +86 \\
\hline \multicolumn{7}{|l|}{1987} \\
\hline June & 235 & 263 & -28 & 84 & 82 & +2 \\
\hline July & 444 & 357 & +87 & 379 & 231 & +148 \\
\hline August & 425 & 255 & +170 & 437 & 247 & +190 \\
\hline September & 227 & 284 & -57 & 197 & 134 & +63 \\
\hline \multicolumn{7}{|l|}{1988} \\
\hline June & 326 & 340 & -14 & 154 & 182 & -28 \\
\hline July & 548 & 287 & +261 & 494 & 314 & +180 \\
\hline August & 445 & 280 & +165 & 437 & 277 & +160 \\
\hline September & 162 & 186 & -24 & 118 & 166 & -48 \\
\hline
\end{tabular}


Similarly, the rate and quantity of sedimentation in lakes are not uniform. Sediment deposition can vary with the seasonal inflow of streams and with fluctuations in lake currents. For example, in cold climates, spring and summer runoff can flush large quantities of sediment into a lake. These sediments will then be distributed throughout the lake, depending on the lake's currents. In winter, when discharge is relatively low and lakes are ice covered, no sediment accumulates.

\section{Streams}

Sediment in streams is transported in suspension and as bedload. Suspended sediment consists of fine particles, usually clay or silt, that are transported in a stream while being held in suspension by the turbulence of flowing water. Bedload consists of coarse sediment, usually sands, gravels, and larger particles, that is transported on or near the streambed.

Suspended-sediment samples were collected at East Fork and West Fork Eklutna Creeks by automatic samplers and correlated with manually collected samples. Samples were collected three times daily in the summer during the 1985-86 water years and twice daily in the summer during the 1987 water year. Samples were also taken at times of discharge measurements in winter.

Bedload was sampled at approximately 2-week intervals during summer seasons of the 1985-87 water years. The samples of bedload were collected using a sampler (Helley and Smith, 1971) designed for collecting coarse material $(0.062-76.2 \mathrm{~mm})$. Sampling time, number of sampling points, stream width and depth, and weight of dry sediment were recorded as a basis for calculating bedload discharge. Trap efficiency of the sampler was assumed to be 1.0. Characteristics of the sampler and procedures to obtain representative samples have not been fully evaluated. In the interim, the U.S. Geological Survey follows a provisional method of obtaining samples at about 20 equally spaced verticals based largely on field tests by Emmett (1979).

\section{Suspended-Sediment Discharge}

In late May, as air temperatures begin to rise above freezing at higher altitudes, glacial meltwater begins to contribute to the streamflow and a corresponding increase in silt-clay concentration occurs. This causes the stream to take on the turbid, milky appearance that is characteristic of glacier-fed streams. Virtually all the sediment in a given year is transported past the gaging sites from this time until the beginning of October, when air temperature decreases and streamflow declines.

The daily sediment concentrations of the East Fork (fig. 21) and West Fork (fig. 22) Eklutna Creeks followed the same patterns and trends as streamflow, but their fluctuations are more pronounced. Twenty-nine suspended-sediment samples were analyzed for sand/fines analysis ( $>0.062 \mathrm{~mm}$ ). For the East Fork Eklutna Creek the samples averaged 76 percent finer than $0.062 \mathrm{~mm}$ and for the West Fork Eklutna Creek samples averaged 80 percent finer than $0.062 \mathrm{~mm}$. Thus, most of the suspended load consists of silt-clay particles with some fine sand. Water/sediment relations that were developed between suspended-sediment transport rate and water discharge for the two sites (fig. 23) showed that for a given discharge, more suspended sediment will be transported past the West Fork site.

The suspended-sediment load for the period June 1 to September 30 for the 1985-87 water years was computed for the East Fork and West Fork basins. Suspended-sediment loads were computed from the mean daily discharge 


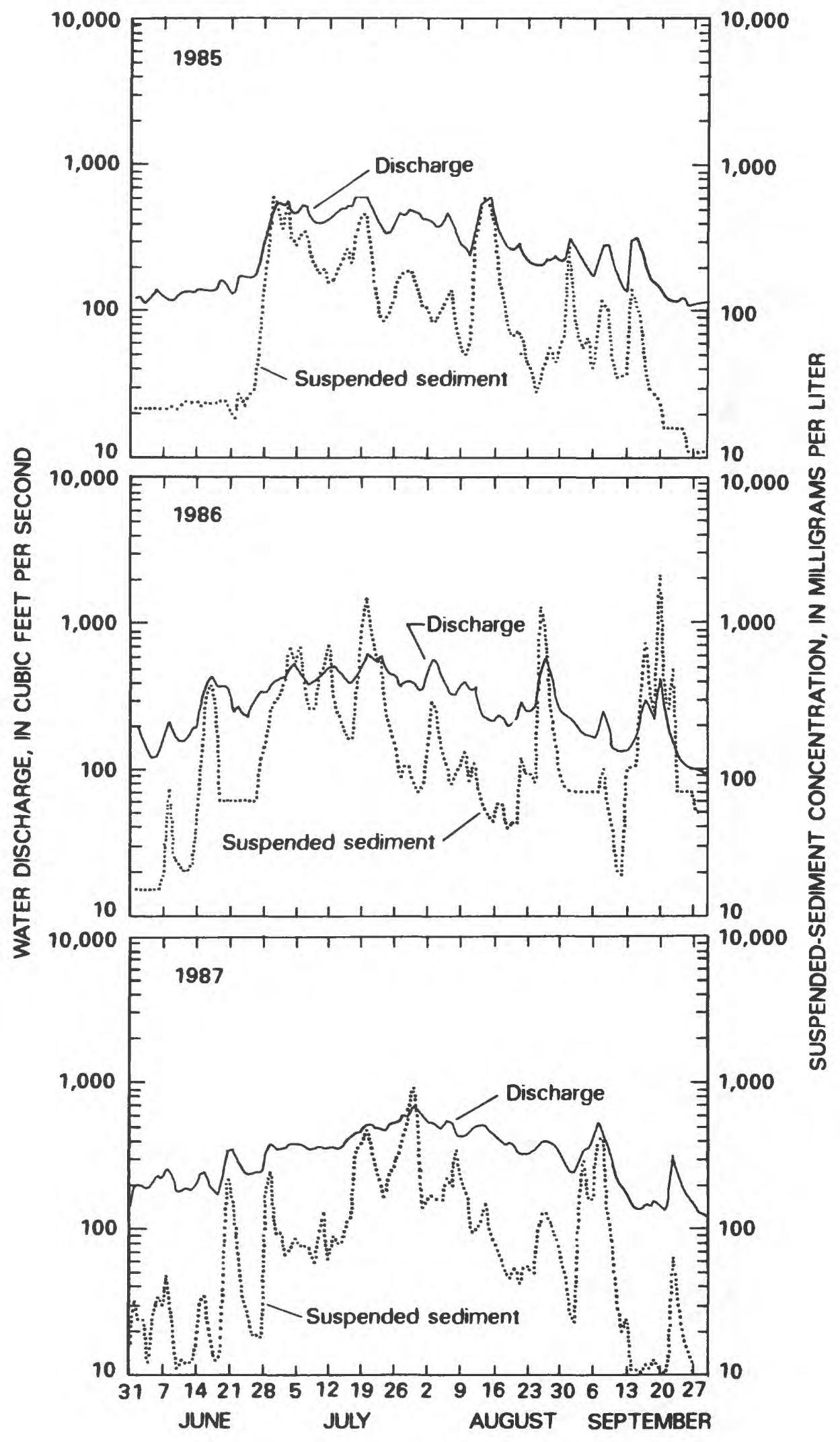

Figure 21.--Daily mean streamflow and suspended-sediment concentration, June to September 1985, 1986, and 1987, East Fork Eklutna Creek. 


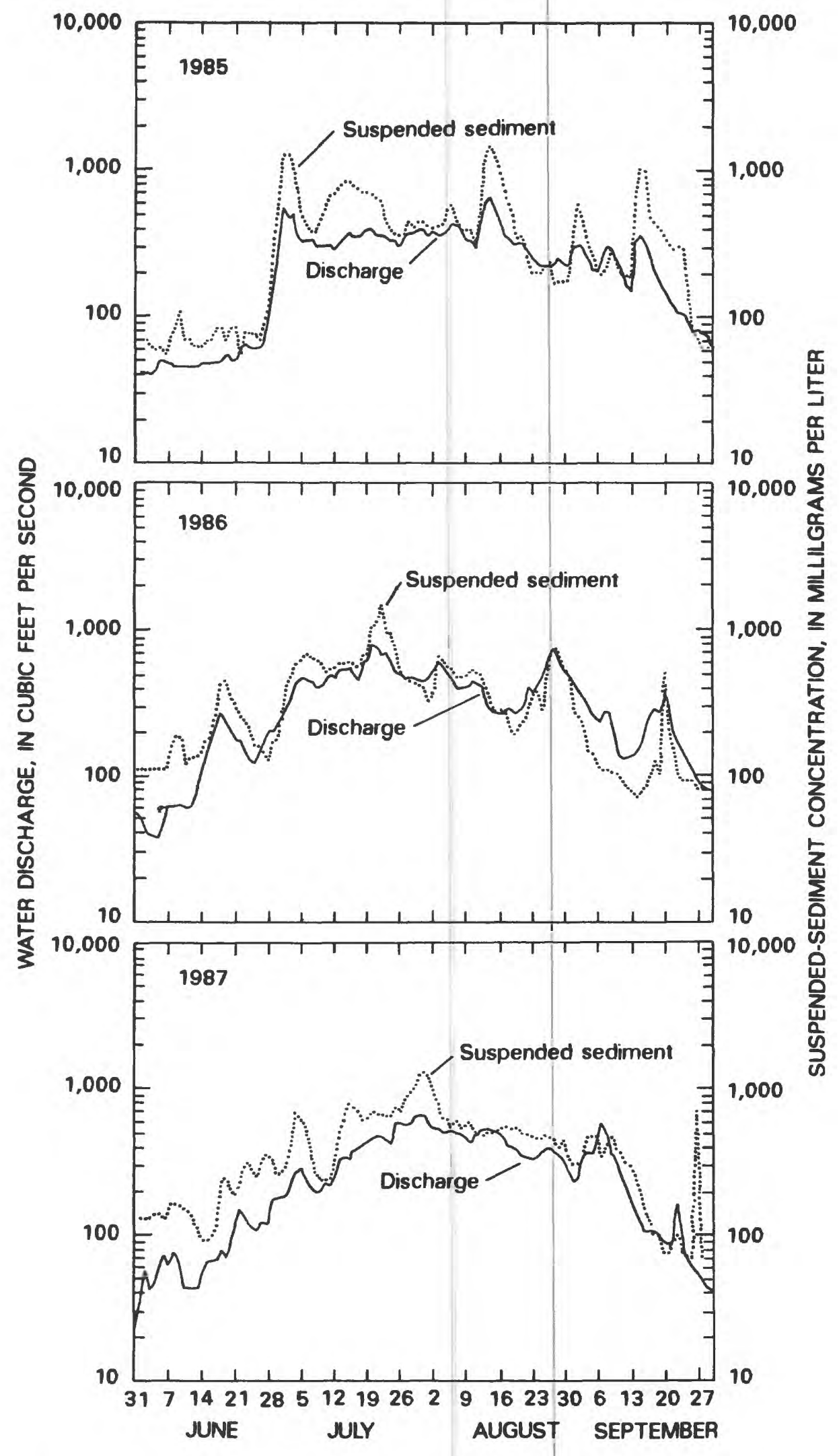

Figure 22.--Daily mean streamflow and suspended-sediment concentration, June to September 1985, 1986, and 1987, West Fork Eklutna Creek. 


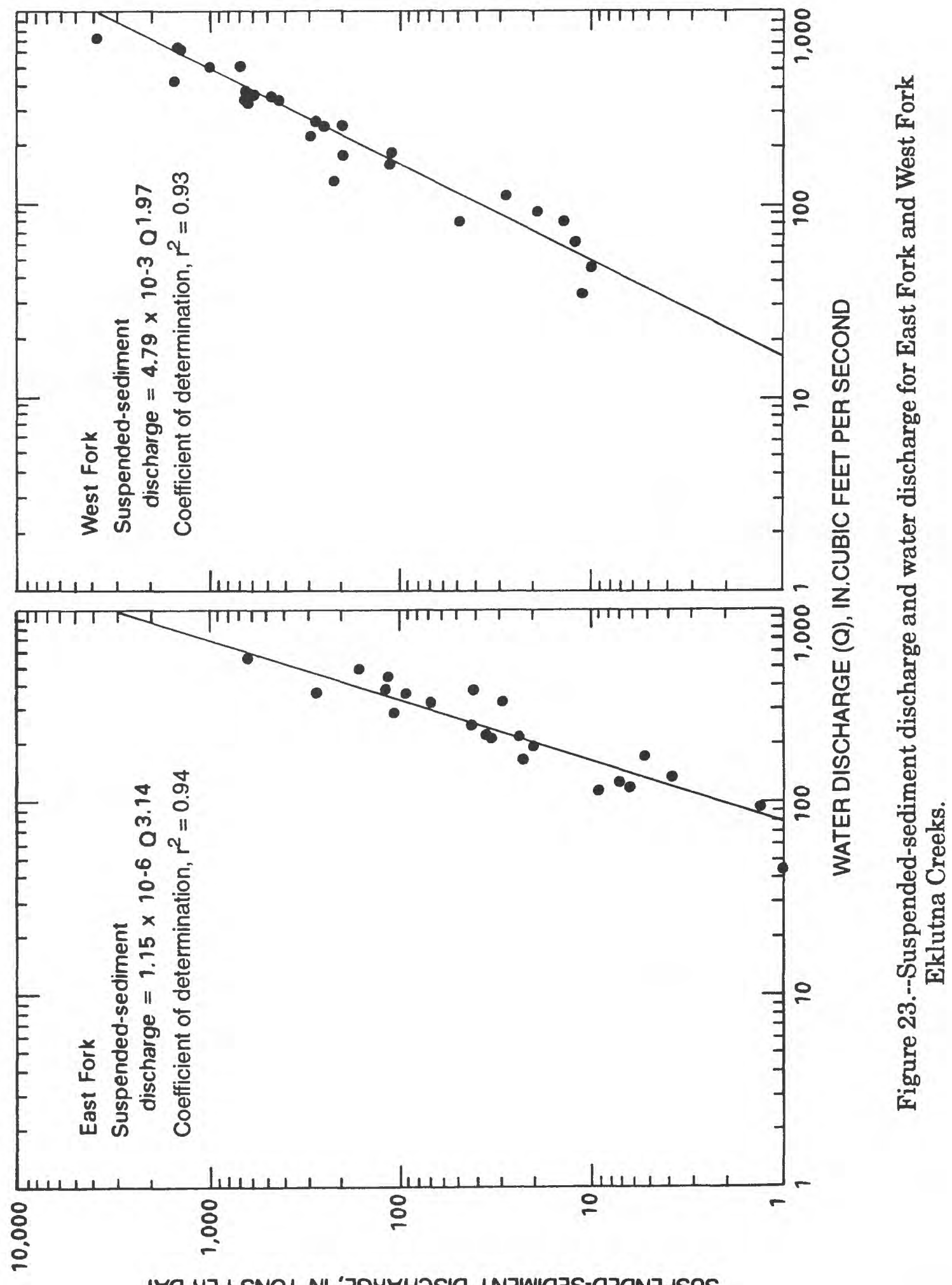

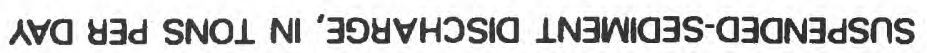


and mean daily suspended-sediment concentration using the method described by Porterfield (1972). The sum of the loads for this period is assumed to represent the annual load, because of low discharge and sediment concentration from October 1 to May 31. Suspended-sediment transport ranged from 17,400 to 30,200 tons at East Fork Eklutna Creek and from 42,900 to 49,600 tons at West Fork Eklutna Creek (fig. 24). Compared on the basis of a yield (tons per square mile), the West Fork basin ( 50 percent glacierized) contributes sediment at a rate approximately two to three times greater than does the East Fork basin (20 percent glacierized).

\section{Bedload Discharge}

Bedload transport is a process characterized by extreme variability both temporally and spatially. On a temporal basis, bedload may range from zero to about four times the actual average bedload of a stream even when the flow is constant (Hubbell, 1987). Significant spatial variability also occurs because bed material commonly will move only within part of the active channel. Thus, an individual bedload sample may provide no more than the roughest estimate of the actual average bedload transport.

The average particle size of bedload was slightly higher than $2 \mathrm{~mm}$ (fine gravel) for both the East Fork and West Fork streams. The median particle size $\left(D_{50}\right)$ of bedload (fig. 25) varied from very coarse sand to fine gravel for both streams. More sand is transported at higher discharges in both streams.

The statistical relations between bedload transport rate and water discharge for the two sites (fig. 26) are not as accurate as the relation of water discharge to suspended-sediment transport (fig. 23). This indicates that bedload discharge is influenced by factors other than water discharge. These factors could include the hydraulic conditions of the stream, the time lag between movement of bed material and runoff, or the efficiency of the HelleySmith sampler. However, the equations for both sites are similar, which indicates that for a given discharge, approximately the same amount of bedload is transported past both sites.

The total bedload for the East Fork and West Fork Eklutna Creeks was estimated using the shift-control method of Colby (1956). In this subjective method, judgement is used to decide whether or not the transport curves in figure 26 should be shifted to pass through or near each individual measurement. Although subjective, the method is considered the most reliable one available. Bedload transported from June 1 to September 30 during the 1985-87 water years ranged from approximately 4,900 to 6,300 tons at East Fork Eklutna Creek and from approximately 3,800 to 5,000 tons at West Fork Eklutna Creek (fig. 27). It is assumed that the total load for this period also represents the annual total. Given the sampling limitations mentioned above and the computation procedures, the total bedload transported past each site during the 1985 and 1986 water years was approximately equal. In 1987, more bedload was transported past the East Fork gage. A possible explanation for this difference may be the influence of a flood that occurred in 1986. The resulting floodwaters may have resupplied the channel with material that was then transported during 1987.

The total annual sediment load (suspended sediment plus bedload) transported past the East Fork Eklutna Creek gage from 1985-87, ranged from 22,300 to 36,500 tons. At the West Fork Eklutna gage, the total annual sediment load transported ranged from 46,700 to 54,600 tons. Bedload constitutes between 14 and 26 percent of the total sediment transported past 


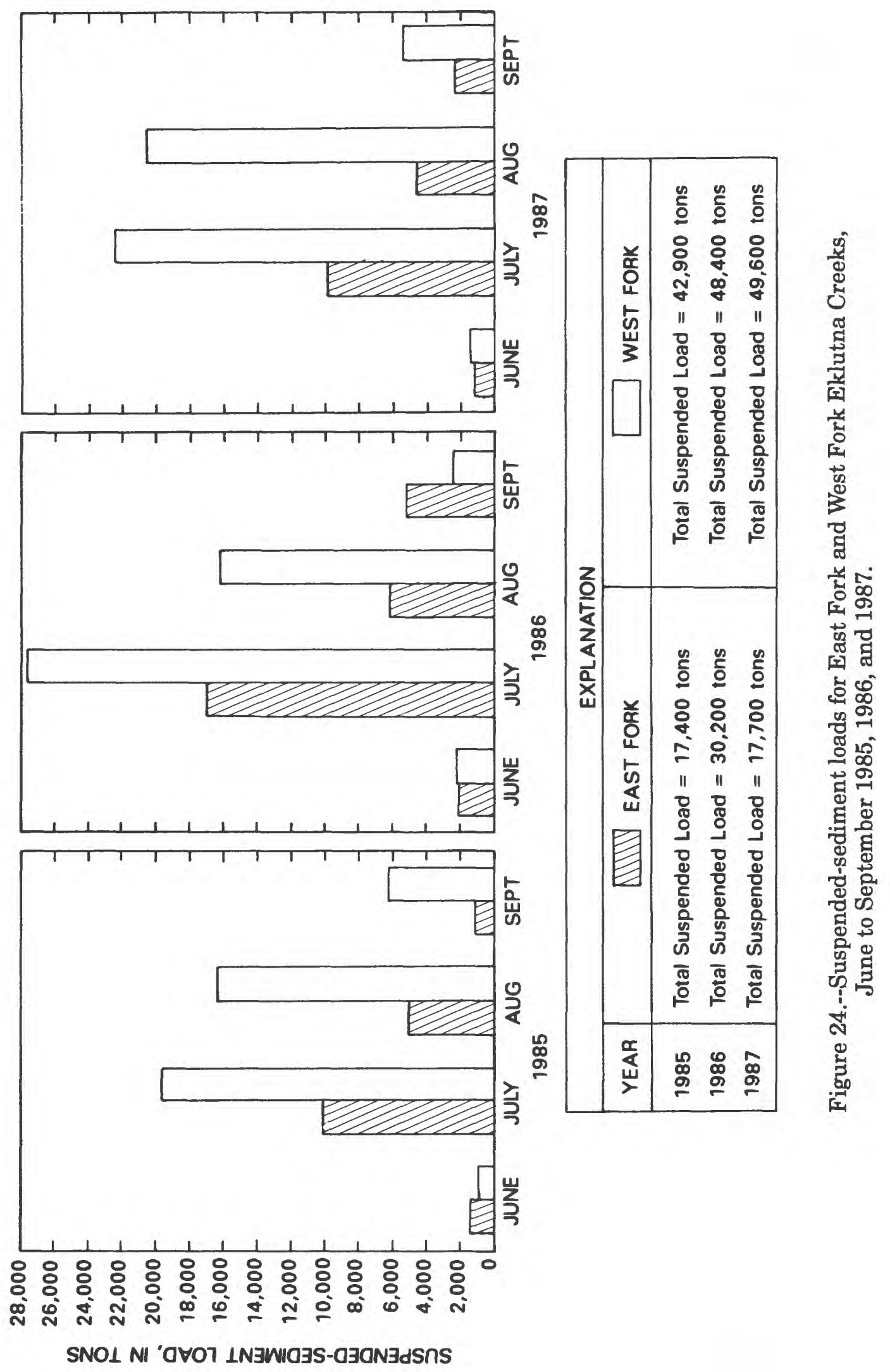




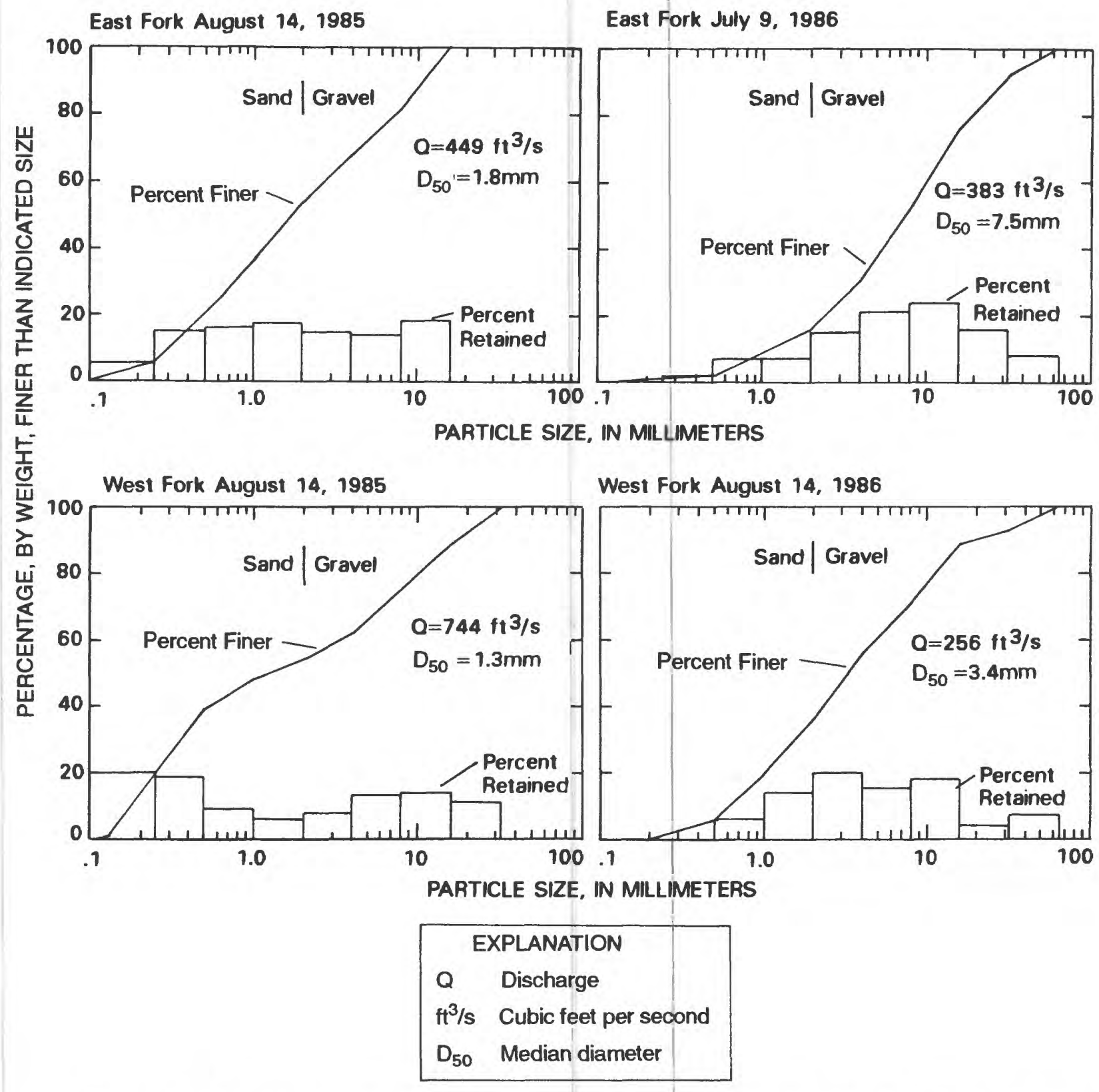

Figure 25.--Particle-size distribution and median diameter of bedload for East Fork and West Fork Eklutna Creeks. 


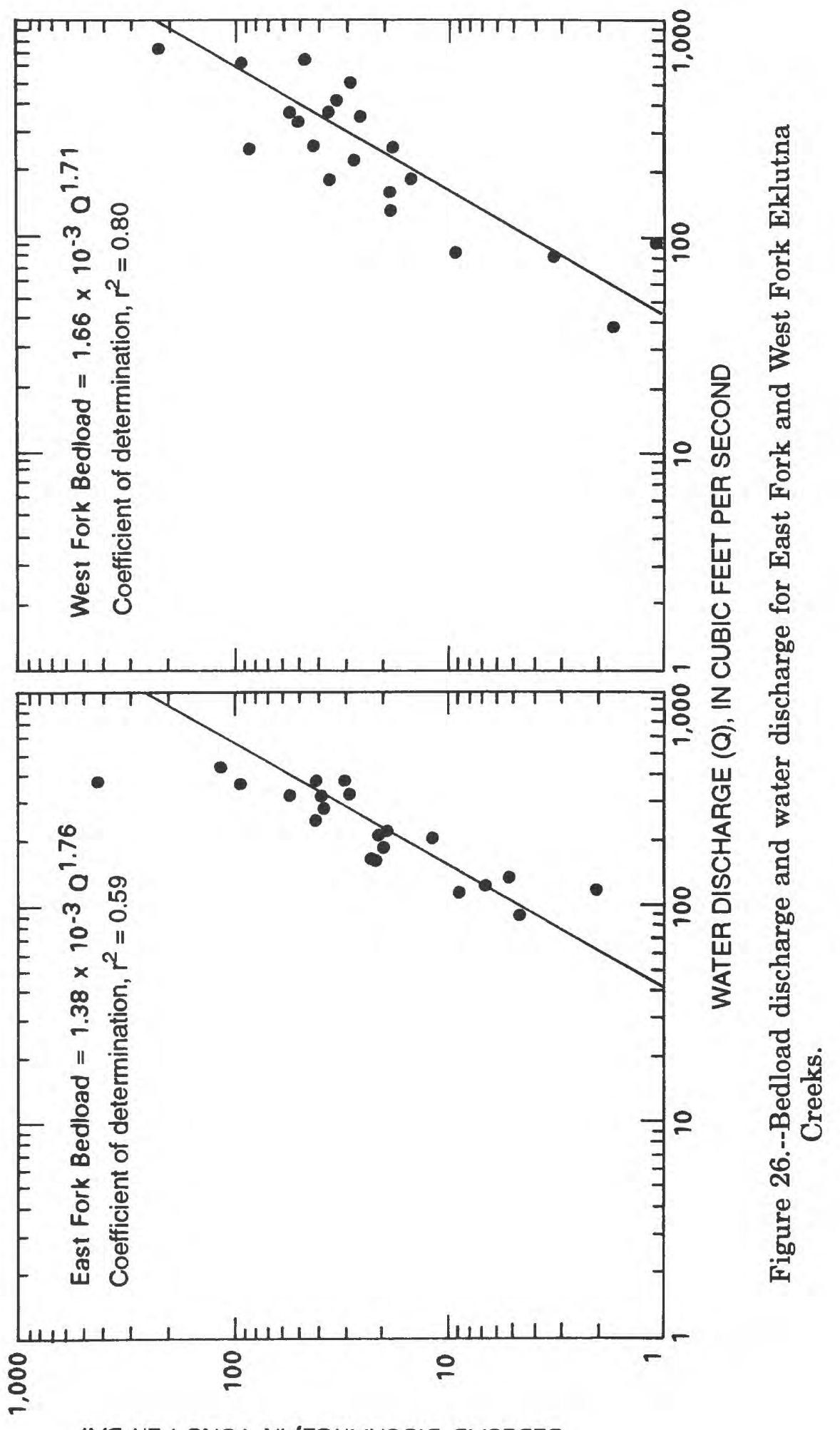

A $\forall$ O 

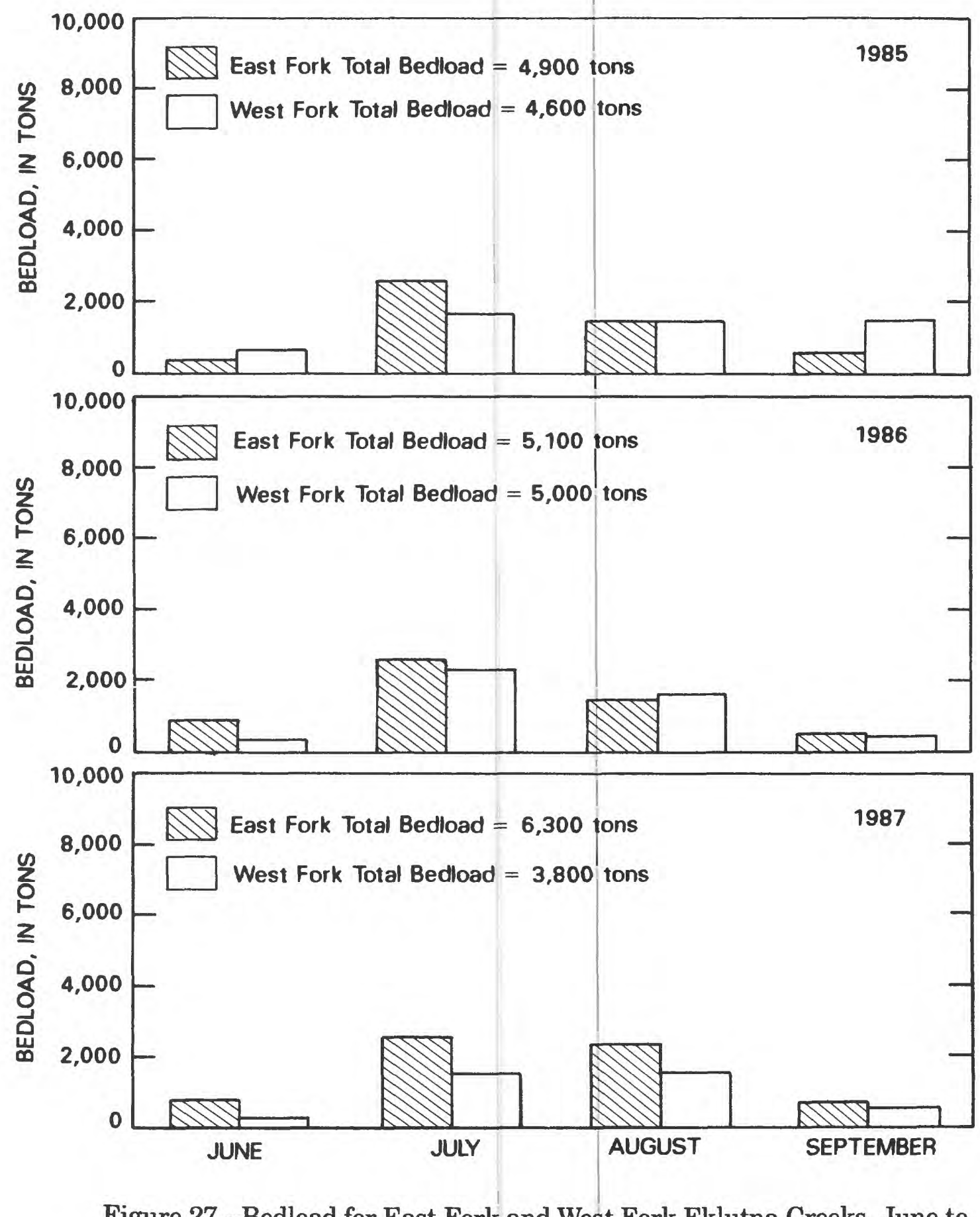

Figure 27.--Bedload for East Fork and West Fork Eklutna Creeks, June to September 1985, 1986, and 1987. 
the East Fork gage and between 7 and 10 percent of the total sediment transported past the West Fork gage.

\section{EklutnaLake}

Eklutna Lake has two primary sedimentation processes: (1) delta progradation and (2) river plume dispersion. Delta progradation is the buildup and movement of sediment at the mouth of an inflow stream caused by the sudden decrease in water velocity. River plume dispersion involves the transport and deposition of medium- and fine-grained particles by the plume of river water as it moves through the lake.

\section{Delta Progradation}

Hydraulic conditions change at the mouth of the inflowing stream that enters Eklutna Lake (plate 1). This stream, which is the combined flow of the East Fork and West Fork Eklutna Creeks, undergoes a rapid decrease in velocity. The stream's coarse sediment load (mostly the bedload) is deposited and the delta that is formed is composed of three layers: a "topset" layer, a "foreset" layer, and a "bottomset" layer (fig. 28). The topset layer consists of sediment deposited on the top surface of the advancing delta, which is continuous with landward alluvial deposits. The foresets are inclined layers of sandy material deposited upon or along an advancing and relatively steep frontal slope. The bottomset is finegrained material (usually silt and clay) deposited slowly on the bed of a quiescent body of water (U.S. Geological Survey, 1977).

The approximate extent of the delta of Eklutna Lake was determined from bathymetric profiles and core samples (fig. 7). This location was then compared with the approximate location of the delta in 1957, which was inferred by aerial photography taken that year. Comparison of the two locations indicates that the delta front has not advanced a significant amount.

As another way of examining the movement of the delta front, an accumulation rate of material was determined as follows:

1) The total bedload entering Eklutna Lake was assumed to equal the sum of the bedload past the East Fork and West Fork gaging stations. This gives a total of approximately 10,000 ton/yr.

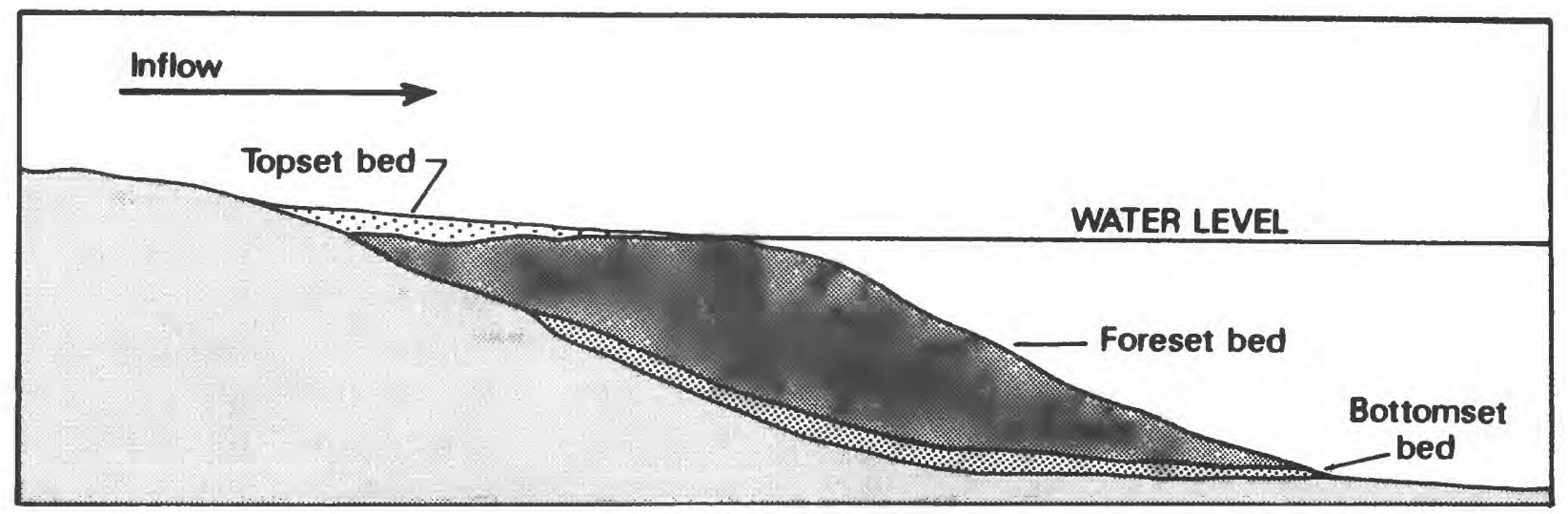

Figure 28.--Types of sediment layers formed by inflow to Eklutna Lake. 
2) On the basis of work by Lara and Pemberton (1963), the density of the bedload was estimated to equal $100 \mathrm{lb} / \mathrm{ft}^{3}$. The accumulation rate was then determined by converting 10,000 ton/yr to a volume based on the unit weight of $100 \mathrm{lb} / \mathrm{ft}^{3}$. This yields a value of approximately 5 acre- $\mathrm{ft} /$ year, which is considered a low rate of accumulation for this study area.

\section{River Plume Dispersion}

When the combined inflow of the East and West Fork Eklutna Creeks enters Eklutna Lake, the finer size material (silt and clay) is not deposited in the delta area but rather continues to move through the lake as a plume and eventually is deposited on the bottom of the lake. This type of plume, commonly referred to as a "density" or "turbidity" current, is defined as a current that carries fine-grained sediment in suspension (Friedman and Sanders, 1978). The density of this current depends on the concentration of suspended sediment and on the water temperature, and is usually different from that of the receiving lake water. The density current will then move into and through the lake as either an overflow, interflow, or underflow of lake water.

The location and extent of the density current in Eklutna Lake was determined by measuring transmissivity. Transmissivity is a function of light transmitted through a given path length relative to the total incident light and is expressed in percentage. Thus, transmissivity is inversely related to turbidity.

In October, the transmissivity measurements indicated a slight underflow (fig. 29A). This would be expected because the lake water has warmed through the preceding summer and fall (isothermal) and the incoming glacierfed streams are colder than the lake. By spring (fig. 29B), the lake water is still isothermal except for the top layer, and no plume is evident. At this time the lake water is clearest (highest transmissivity), reflecting the fact that many of the fine particles have settled to the bottom of the lake. By the end of spring and first part of summer, the lake may be characterized by small overflow (fig. 29C). However, when the major inflow to Eklutna Lake occurs from the end of June through August, a distinct interflow occurs (fig. 29D). It is during this period that most of the fine-grained suspended sediments enter Eklutna Lake and that transmissivity values are lowest. In mid-September, the process repeats itself when inflow begins to decrease and the lake is completely mixed.

\section{Rate of Sediment Accumulation}

The proportion of sediment retained in Eklutna Lake--called its "trap efficiency"--has been estimated at 97 percent (Coffin and Ashton, 1986). Assuming that the total amount of sediment entering Eklutna Lake is the sum of the sediment transported past the East Fork and West Fork Eklutna gages, an average total of approximately 76,000 ton/yr remains in the lake.

Another way of representing the accumulation rate is on a volume basis. This is determined by dividing the amount of sediment that enters the lake by the unit weight of the sediment. For Eklutna Lake, the unit weight was determined from the six core samples (fig. 7) by obtaining the dry weight of each sample and the volume of the core it occupied. The average unit weight of these samples was 47 $\mathrm{lb} / \mathrm{ft}^{3}$. The accumulation rate was then determined by converting 76,000 ton/yr to a volume based on a unit weight of $47 \mathrm{lb} / \mathrm{ft}^{3}$, yielding a value of approximately 74 acre$\mathrm{ft} / \mathrm{yr}$. 
TRANSMISSIVITY, IN PERCENT

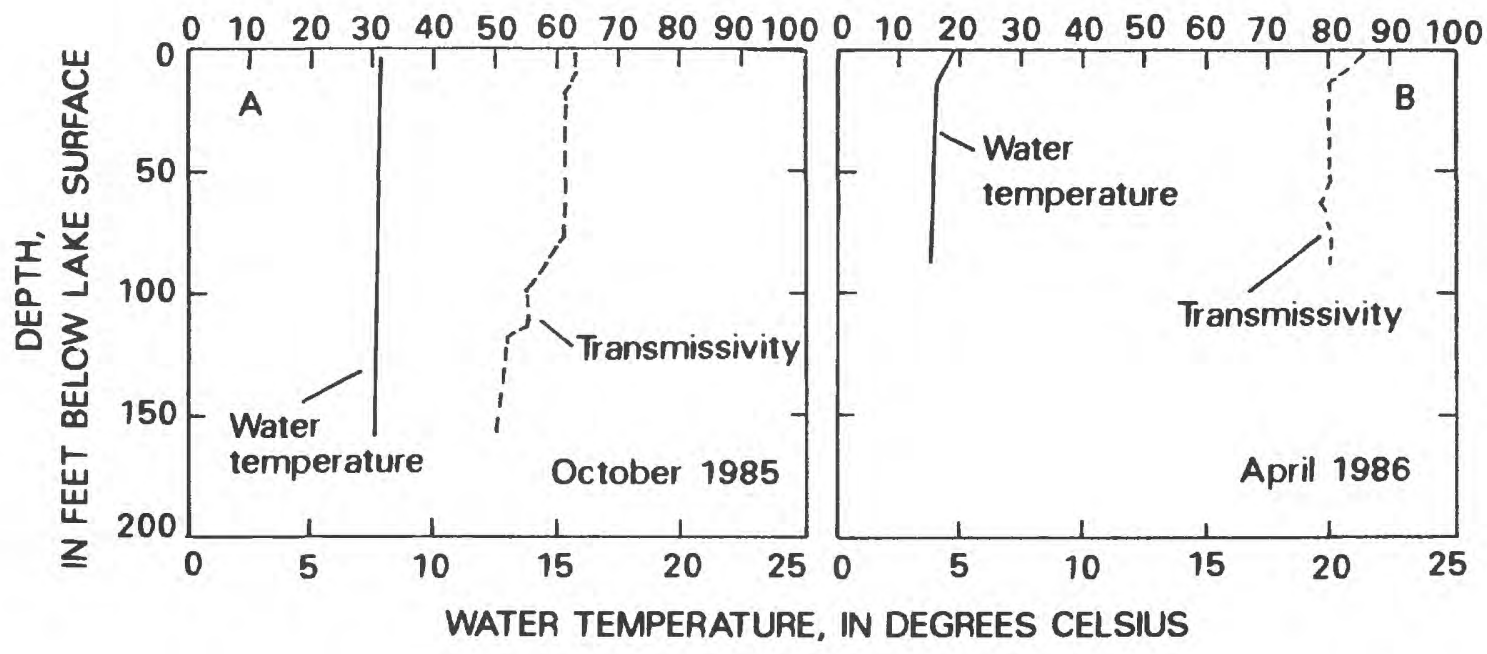

TRANSMISSIVITY, IN PERCENT

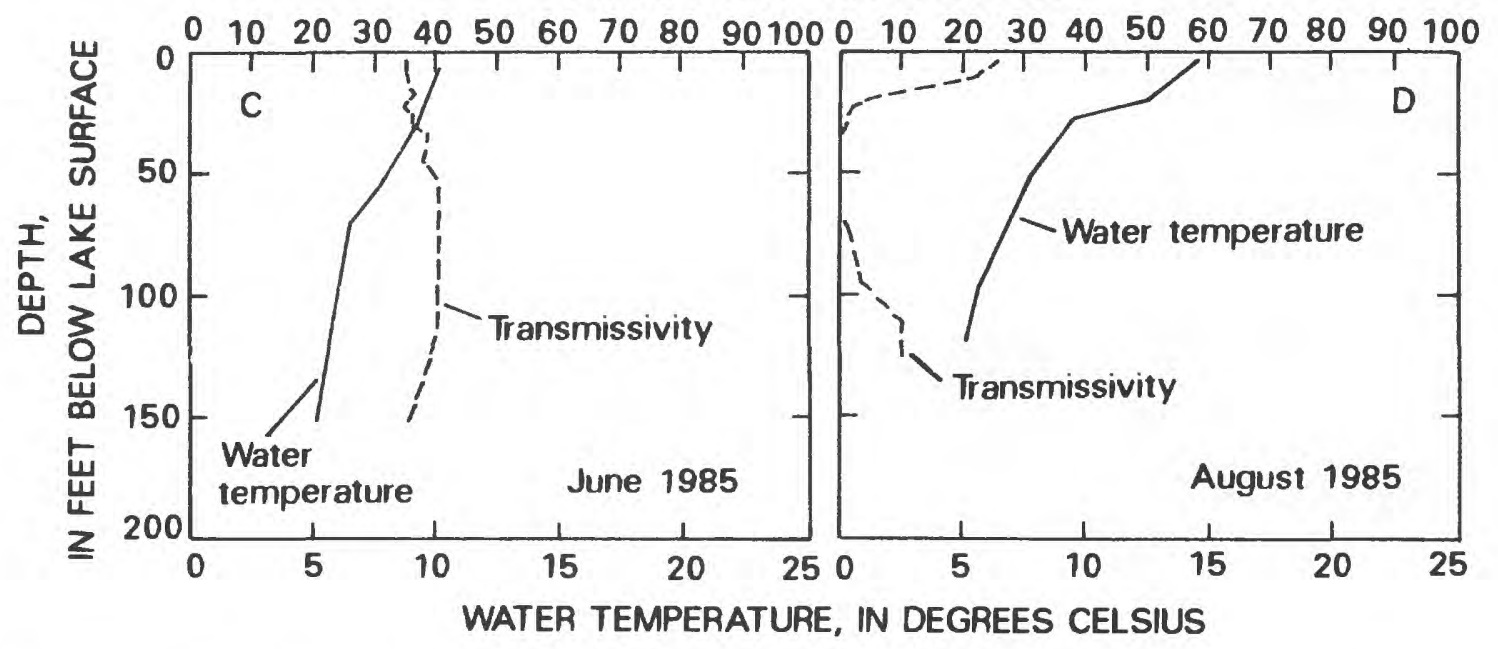

Figure 29.--Profiles of density current in Eklutna Lake at various times showing: A, underflow; B, no density current; C, overflow; and D, interflow.

\section{WATER STORAGE IN EKLUTNA LAKE}

The intake that supplies water to the Eklutna Power Plant and the Eklutna Water Project is at altitude $814.00 \mathrm{ft}$ above sea level. Any volume of water above this altitude is often referred to as the "active storage." The active storage of Eklutna Lake, computed by the Alaska Power Administration, ranges from 0 acre-ft at $814.00 \mathrm{ft}$ to 191,807 acre-ft at 875.90 $\mathrm{ft}$ (table 8). The active storage determined from a bathymetric survey of Eklutna Lake made in 1986 at altitude $860.00 \mathrm{ft}$ was 145,400 acre- $\mathrm{ft}$. Because this volume is within 5 percent of the computed value, it is assumed that the values in table 8 are accurate.

The standard equation used in storage analysis is $I-O=\Delta S$, where $I$ is inflow, $O$ is outflow, and $\Delta S$ is change in storage. Storage of Eklutna Lake was analyzed to determine the inflow characteristics of the lake by using (1) the outflow records provided by the Eklutna Power Plant, (2) the lake altitudes to determine changes in storage capacity (table 8), and (3) the inflow from the East and West Fork Eklutna Creeks. This analysis (table 9) indicates that most of the inflow occurs in July and 


\section{Table 8.--Active storage of Eklutna Lake}

[Water-surface altitude in feet above sea level; data from the Alaska Power Administration]

\begin{tabular}{|c|c|c|c|c|c|c|c|c|c|c|}
\hline \multirow{2}{*}{$\begin{array}{l}\text { Water } \\
\text { surface } \\
\text { altitude }\end{array}$} & \multicolumn{9}{|c|}{ Storage at tenths of a foot (acre-feet) } & \multirow[b]{2}{*}{.9} \\
\hline & .0 & .1 & .2 & .3 & .4 & .5 & .6 & .7 & .8 & \\
\hline 814 & 0 & 282 & 564 & 846 & 1,128 & 1,409 & 1,691 & 1,973 & 2,255 & 2,537 \\
\hline 815 & 2,819 & 3,102 & 3,385 & 3,667 & 3,950 & 4,233 & 4,516 & 4,799 & 5,081 & 5,364 \\
\hline 816 & 5,647 & 5,931 & 6,215 & 6,498 & 6,782 & 7,066 & 7,350 & 7,634 & 7,917 & 8,201 \\
\hline 817 & 8,484 & 8,770 & 9,054 & 9,339 & 9,623 & 9,908 & 10,193 & 10,477 & 10,762 & 11,046 \\
\hline 818 & 11,331 & 11,616 & 11,902 & 12,187 & 12,473 & 12,758 & 13,044 & 13,329 & 13,615 & 13,900 \\
\hline 819 & 14,186 & 14,472 & 14,759 & 15,045 & 15,331 & 15,617 & 15,904 & 16,190 & 16,476 & 16,763 \\
\hline 820 & 17,049 & 17,336 & 17,623 & 17,910 & 18,197 & 18,484 & 18,771 & 19,058 & 19,345 & 19,632 \\
\hline 821 & 19,919 & 20,206 & 20,496 & 20,781 & 21,069 & 21,356 & 21,644 & 21,931 & 22,219 & 22,506 \\
\hline 822 & 22,794 & 23,082 & 23,370 & 23,658 & 23,946 & 24,234 & 24,523 & 24,811 & 25,099 & 25,387 \\
\hline 823 & 25,675 & 25,963 & 26,252 & 26,540 & 26,829 & 27,117 & 27,406 & 27,694 & 27,983 & 28,271 \\
\hline 824 & 28,560 & 28,849 & 29,138 & 29,427 & 29,716 & 30,005 & 30,294 & 30,583 & 30,872 & 31,161 \\
\hline 825 & 31,450 & 31,739 & 32,029 & 32,318 & 32,608 & 32,897 & 33,187 & 33,476 & 33,766 & 34,055 \\
\hline 826 & 34,345 & 34,635 & 34,925 & 35,215 & 35,505 & 35,795 & 36,085 & 36,375 & 36,665 & 36,955 \\
\hline 827 & 37,245 & 37,535 & 37,826 & 38,116 & 38,407 & 38,697 & 38,988 & 39,278 & 39,569 & 39,859 \\
\hline 828 & 40,150 & 40,441 & 40,732 & 41,023 & 41,314 & 41,605 & 41,897 & 42,188 & 42,479 & 42,770 \\
\hline 829 & 43,061 & 43,353 & 43,644 & 43,936 & 44,228 & 44,519 & 44,811 & 45,103 & 45,395 & 45,686 \\
\hline 830 & 45,978 & 46,270 & 46,563 & 46,855 & 47,148 & 47,440 & 47,733 & 48,025 & 48,318 & 48,610 \\
\hline 831 & 48,903 & 49,196 & 49,490 & 49,783 & 50,077 & 50,370 & 50,664 & 50,957 & 51,251 & 51,544 \\
\hline 832 & 51,823 & 52,132 & 52,427 & 52,722 & 53,016 & 53,311 & 53,606 & 53,900 & 54,195 & 54,489 \\
\hline 833 & 54,784 & 55,080 & 55,375 & 55,671 & 55,967 & 56,262 & 56,558 & 56,854 & 57,150 & 57,445 \\
\hline 834 & 57,741 & 58,038 & 58,335 & 58,631 & 58,928 & 59,225 & 59,522 & 59,819 & 60,115 & 60,412 \\
\hline 835 & 60,709 & 61,007 & 61,305 & 61,603 & 61,901 & 62,198 & 62,496 & 62,794 & 63,092 & 63,390 \\
\hline 836 & 63,688 & 63,987 & 64,286 & 64,585 & 64,884 & 65,183 & 65,483 & 65,782 & 66,081 & 66,380 \\
\hline 837 & 66,679 & 66,979 & 67,279 & 67,580 & 67,880 & 68,180 & 68,480 & 68,781 & 69,081 & 69,381 \\
\hline 838 & 69,681 & 69,982 & 70,284 & 70,585 & 70,887 & 71,188 & 71,489 & 71,791 & 72,092 & 72,394 \\
\hline 839 & 72,695 & 72,998 & 73,300 & 73,603 & 73,905 & 74,208 & 74,511 & 74,813 & 75,116 & 75,418 \\
\hline 840 & 75,721 & 76,025 & 76,328 & 76,632 & 76,935 & 77,239 & 77,543 & 77,846 & 78,150 & 78,453 \\
\hline 841 & 78,757 & 79,061 & 79,366 & 79,670 & 79,975 & 80,279 & 80,584 & 80,888 & 81,193 & 81,497 \\
\hline 842 & 81,802 & 82,107 & 82,413 & 82,718 & 83,023 & 83,328 & 83,634 & 83,939 & 84,244 & 84,550 \\
\hline 843 & 84,855 & 85,161 & 85,467 & 85,774 & 86,080 & 86,386 & 86,692 & 86,998 & 87,305 & 87,611 \\
\hline 844 & 87,917 & 88,224 & 88,531 & 88,838 & 89,145 & 89,452 & 89,759 & 90,066 & 90,373 & 90,680 \\
\hline 845 & 90,987 & 91,295 & 91,603 & 91,911 & 92,219 & 92,526 & 92,834 & 93,142 & 93,450 & 93,758 \\
\hline 846 & 94,066 & 94,375 & 94,684 & 94,992 & 95,301 & 95,610 & 95,919 & 96,228 & 96,536 & 96,845 \\
\hline 847 & 97,154 & 97,464 & 97,773 & 98,083 & 98,393 & 98,702 & 99,012 & 99,322 & 99,632 & 99,941 \\
\hline 848 & 100,251 & 100,562 & 100,872 & 101,183 & 101,493 & 101,804 & 102,115 & 102,425 & 102,736 & 103,046 \\
\hline 849 & 103,357 & 103,668 & 103,980 & 104,291 & 104,603 & 104,914 & & & & 106,160 \\
\hline 850 & 106,472 & 106,784 & 107,097 & 107,409 & 107,722 & 108,034 & 108,347 & 108,659 & 108,972 & 109,284 \\
\hline 851 & 109,597 & 109,910 & 110,224 & 110,537 & 110,851 & 111,164 & 111,478 & 111,791 & 112,105 & 112,418 \\
\hline 852 & 112,732 & 113,047 & 113,361 & 113,676 & 113,990 & 114,305 & 114,620 & 114,934 & 115,249 & 115,563 \\
\hline 853 & 115,878 & 116,194 & 116,510 & 116,825 & 117,141 & 117,457 & 117,773 & 118,089 & 118,404 & 118,720 \\
\hline
\end{tabular}


Table 8.--Active storage of Eklutna Lake--Continued

\begin{tabular}{|c|c|c|c|c|c|c|c|c|c|c|}
\hline \multirow{2}{*}{$\begin{array}{l}\text { Water } \\
\text { surface } \\
\text { altitude }\end{array}$} & \multicolumn{9}{|c|}{ Storage at tenths of a foot (acre-feet) } & \multirow[b]{2}{*}{.9} \\
\hline & .0 & .1 & .2 & .3 & .4 & .5 & .6 & .7 & .8 & \\
\hline 854 & 119,036 & 119,353 & 119,670 & 119,987 & 120,304 & 120,620 & 120,937 & 121,254 & 121,571 & 121,888 \\
\hline 855 & 122,205 & 122,523 & 122,841 & 123,159 & 123,477 & 123,795 & 124,114 & 124,432 & 124,750 & 125,068 \\
\hline 856 & 125,386 & 125,705 & 126,025 & 126,344 & 126,664 & 126,983 & 127,302 & 127,622 & 127,941 & 128,261 \\
\hline 857 & 128,380 & 128,901 & 129,221 & 129,542 & 129,863 & 130,183 & 130,504 & 130,825 & 131,146 & 131,466 \\
\hline 858 & 131,787 & 132,109 & 132,431 & 132,753 & 133,075 & 133,397 & 133,719 & 134,041 & 134,363 & 134,685 \\
\hline 859 & 135,007 & 135,330 & 135,654 & 135,977 & 136,300 & 136,623 & 136,947 & 137,270 & 137,593 & 137,917 \\
\hline 860 & 138,240 & 138,565 & 138,889 & 139,214 & 139,539 & 139,863 & 140,188 & 140,513 & 140,838 & 141,162 \\
\hline 861 & 141,487 & 141,813 & 142,139 & 142,465 & 142,791 & 143,117 & 143,444 & 143,770 & 144,096 & 144,422 \\
\hline 862 & 144,748 & 145,075 & 145,403 & 145,730 & 146,058 & 146,385 & 146,713 & 147,040 & 147,368 & 147,695 \\
\hline 863 & 148,023 & 148,352 & 148,681 & 149,010 & 149,339 & 149,668 & 149,997 & 150,326 & 150,655 & 150,984 \\
\hline 864 & 151,313 & 151,643 & 151,974 & 152,304 & 152,635 & 152,965 & 153,296 & 153,626 & 153,957 & 154,287 \\
\hline 865 & 154,618 & 154,950 & 155,282 & 155,614 & 155,946 & 156,278 & 156,611 & 156,943 & 157,275 & 157,607 \\
\hline 866 & 157,939 & 158,273 & 158,606 & 158,940 & 159,274 & 159,607 & 159,941 & 160,275 & $160 ; 609$ & 160,942 \\
\hline 867 & 161,276 & 161,611 & 161,947 & 162,282 & 162,618 & 162,953 & 163,288 & 163,624 & 163,959 & 164,295 \\
\hline 868 & 164,630 & 164,967 & 165,304 & 165,641 & 165,978 & 166,315 & 166,653 & 166,990 & 167,327 & 167,664 \\
\hline 869 & 168,001 & 168,340 & 168,679 & 169,018 & 169,357 & 169,695 & 170,034 & 170,373 & 170,712 & 171,051 \\
\hline 870 & 171,390 & 171,731 & 172,072 & 172,412 & 172,753 & 173,094 & 173,435 & 173,776 & 174,116 & 174,457 \\
\hline 871 & 174,798 & 175,141 & 175,484 & 175,827 & 176,170 & 176,512 & 176,855 & 177,198 & 177,541 & 177,884 \\
\hline 872 & 178,227 & 178,572 & 178,917 & 179,262 & 179,607 & 179,952 & 180,297 & 180,642 & 180,987 & 181,332 \\
\hline 873 & 181,677 & 182,024 & 182,371 & 182,719 & 183,066 & 183,413 & 183,760 & 184,107 & 184,455 & 184,802 \\
\hline 874 & 185,149 & 185,498 & 185,848 & 186,197 & 186,547 & 186,896 & 187,245 & 187,595 & 187,944 & 188,294 \\
\hline 875 & 188,643 & 188,995 & 189,346 & 189,698 & 190,049 & 190,401 & 190,753 & 191,104 & 191,456 & 191,807 \\
\hline
\end{tabular}


Table 9.-- Change in storage, outflow, and inflow for Eklutna Lake, 1985-88

\begin{tabular}{|c|c|c|c|c|c|}
\hline $\begin{array}{l}\text { Year } \\
\text { and } \\
\text { month }\end{array}$ & $\begin{array}{l}\text { Change in } \\
\text { storage } \\
\text { (acre-feet) } \\
\quad \Delta S\end{array}$ & $\begin{array}{l}\text { Outflow } \\
\text { (acre-feet) } \\
0\end{array}$ & $\begin{array}{l}\text { Combined ir } \\
\text { East Fork ar } \\
\text { West Fork } \\
\text { Creeks } \\
\text { (acre-feet) } \\
\quad \text { I }\end{array}$ & $\begin{array}{l}\text { Inflow not } \\
\text { accounted for } \\
\text { (acre-feet) }\end{array}$ & $\begin{array}{l}\text { Percentage } \\
\text { of inflow } \\
\text { accounted for } \\
\text { by East and } \\
\text { West Fork }\end{array}$ \\
\hline \multicolumn{6}{|l|}{1985} \\
\hline June & $-4,044$ & 20,299 & 13,360 & 2,895 & 82 \\
\hline July & $+50,046$ & 11,677 & 50,950 & 10,773 & 82 \\
\hline August & $+40,074$ & 8,821 & 41,120 & 7,775 & 84 \\
\hline September & $+16,994$ & 12,592 & 22,750 & 6,836 & 76 \\
\hline October & $-11,901$ & 20,299 & 5,430 & 2,968 & 65 \\
\hline November & $-13,303$ & 17,053 & 1,877 & 1,873 & 50 \\
\hline December & $-15,897$ & 20,246 & 1,569 & 2,780 & 36 \\
\hline \multicolumn{6}{|l|}{1986} \\
\hline January & $-20,225$ & 23,161 & 1,311 & 1,625 & 45 \\
\hline February & $-20,977$ & 22,630 & 907 & 746 & 55 \\
\hline March & $-22,207$ & 23,300 & 627 & 466 & 57 \\
\hline April & $-25,846$ & 28,849 & 1,298 & 1,705 & 57 \\
\hline May & $+7,394$ & 287 & 4,409 & 3,272 & 57 \\
\hline June & $+21,587$ & 5,418 & 22,040 & 4,965 & 82 \\
\hline July & $+57,874$ & 6,890 & 57,860 & 6,904 & 89 \\
\hline August & $+32,531$ & 15,970 & 46,070 & 2,431 & 95 \\
\hline September & $+7,037$ & 20,520 & 22,870 & 4,687 & 83 \\
\hline October & $-3,726$ & 25,260 & 15,680 & 5,854 & 73 \\
\hline November & $-13,097$ & 20,641 & 4,139 & 3,405 & 55 \\
\hline December & $-13,631$ & 19,665 & 2,290 & 3,744 & 38 \\
\hline \multicolumn{6}{|l|}{1987} \\
\hline January & $-19,531$ & 23,645 & 1,491 & 2,623 & 36 \\
\hline February & $-18,560$ & 20,944 & 1,334 & 1,050 & 56 \\
\hline March & $-25,647$ & 26,723 & 1,280 & 204 & 86 \\
\hline April & $-17,723$ & 19,844 & 835 & 1,286 & 40 \\
\hline May & $+8,489$ & 34 & 4,593 & 3,930 & 54 \\
\hline June & $+26,393$ & 0 & 19,010 & 7,383 & 72 \\
\hline July & $+51,688$ & 12,936 & 50,650 & 13,974 & 78 \\
\hline August & $+48,356$ & 17,445 & 53,020 & 12,781 & 80 \\
\hline September & $+10,259$ & 20,937 & 25,220 & 5,976 & 81 \\
\hline October & $-12,446$ & 24,364 & 6,970 & 4,948 & 58 \\
\hline November & $-11,436$ & 20,642 & 2,909 & 6,297 & 32 \\
\hline December & $-24,358$ & 19,665 & 1,898 & 6,591 & 22 \\
\hline \multicolumn{6}{|l|}{1988} \\
\hline January & $-24,111$ & 27,597 & 1,403 & 2,083 & 40 \\
\hline February & $-17,376$ & 20,352 & 1,033 & 1,943 & 35 \\
\hline March & $-13,122$ & 16,182 & 902 & 2,158 & 29 \\
\hline April & $-9,988$ & 14,202 & 944 & 3,270 & 22 \\
\hline May & $-10,629$ & 26,603 & 5,841 & 10,133 & 36 \\
\hline June & $+20,111$ & 22,025 & 28,610 & 13,526 & 68 \\
\hline July & $+61,410$ & 19,944 & 64,110 & 17,244 & 79 \\
\hline August & $+33,771$ & 30,198 & 54,250 & 9,719 & 85 \\
\hline September & $-5,716$ & 30,126 & 16,680 & 7,730 & 68 \\
\hline
\end{tabular}


August, and that the West Fork and East Fork Eklutna Creeks contribute a large part (80 percent) of water to Eklutna Lake. During winter and spring months, the amount of inflow to the lake is negligible. Most of the inflow is probably derived from ground water.

With the completion of the Eklutna Water Project, Eklutna Lake now serves two purposes: power generation and water supply. Inspection of the operation records of the Eklutna Power Plant (1966-88) indicates that the average outflow of Eklutna Lake is $306\left(\mathrm{ft}^{3} / \mathrm{s}\right) / \mathrm{d}$. The yearly average outflow has been as high as $388\left(\mathrm{ft}^{3} / \mathrm{s}\right) / \mathrm{d}$ and monthly outflow has been as high as $520\left(\mathrm{ft}^{3} / \mathrm{s}\right) / \mathrm{d}$. The Municipality of Anchorage at present could draw $54\left(\mathrm{ft}^{3} / \mathrm{s}\right) / \mathrm{d}(35 \mathrm{Mgal} / \mathrm{d})$ from the lake and as much as $108\left(\mathrm{ft}^{3} / \mathrm{s}\right) / \mathrm{d}(70 \mathrm{Mgal} / \mathrm{d})$ if the treatment plant were expanded.

To determine if there will be an adequate supply of water for both purposes, a storage frequency analysis was done using a model developed by Glover (1984). The model first determines whether the total monthly inflow follows a normal, log-normal, Gumbel, Pearson, or log-Pearson distribution using the methods outlined by Riggs and Hardison (1973). A cumulative probability of inflow function is then developed for each month. Conventional flow routing $(\mathrm{I}-\mathrm{O}=\Delta \mathrm{S}$ ) is done to generate 12 sets of data points relating initial storage, final storage, and total monthly inflows. Applying the routing relations to the inflow functions produces a transition probability matrix for each month, which defines the chance of reservoir storage changing from any level to any new level. Finally, a system of probability equations is written that describes the final storage probabilities for each month in terms of initial storage probabilities and the monthly transition matrix. By operating the program with a given set of storage capacities and outflow rates, a set of risks of failure are calculated as the probability of exceeding the available storage capacity.

Input data to the model consist of inflow discharge, outflow rate, and storage capacity. For this study, inflow discharge was assumed to be the change in storage plus outflow. Additionally, the user must specify the number of storage layers. The number of layers used to divide the lake storage can have an effect on the error of the analysis and thus the procedure used was to run the model with different numbers of layers to insure that reasonable answers resulted.

Several runs of the storage frequency model were made using different withdrawal rates. The analyses showed that the months of May and June would have the highest probabilities of storage capacities being exceeded (table 10). Probabilities are relatively low (10 percent) that the storage capacity will be exceeded unless withdrawal rates exceed $450 \mathrm{ft}^{3} / \mathrm{s}$.

\section{SUMMARY AND CONCLUSIONS}

Glacier mass balance, runoff, sediment transport and deposition, and lake storage characteristics in the Eklutna Lake basin were studied. Significant findings are:

1) Mass balance measurements made on Eklutna Glacier from 1985 to 1988 did not indicate any significant changes in the glacier. The accumulation area ration (AAR) for each year during the study indicates that the glacier is in an equilibrium state.

2) Two main streams flow into Eklutna Lake: the East Fork Eklutna Creek drains a 38.2-square-mile basin which is 20 percent glacierized ( 7.6 square miles), and the West Fork Eklutna Creek drains a 25.4-squaremile basin which is 50 percent glacierized (12.2 square miles). 


\section{Table 10.-- Risks of failure to supply withdrawal rates during the year at Eklutna Lake}

$\left[\mathrm{ft} \mathrm{t}^{3} / \mathrm{s}\right.$, cubic feet per second.]

\begin{tabular}{|c|c|c|c|c|c|c|c|c|c|c|c|c|}
\hline $\begin{array}{l}\text { With- } \\
\text { drawal } \\
\text { rate } \\
\left(\mathrm{ft}^{3} / \mathrm{s}\right)\end{array}$ & Jan. & Feb. & Mar. & Apr. & May & $\begin{array}{l}\text { June } \\
\text { (percen }\end{array}$ & $\begin{array}{l}\text { July } \\
\text { tt) }\end{array}$ & Aug. & Sept. & Oct. & Nov. & Dec. \\
\hline 360 & 0.01 & 0.1 & 0.3 & 1.2 & 3.1 & 2.6 & 0.2 & 0 & 0 & 0 & 0 & 0 \\
\hline 410 & .04 & .3 & 1.2 & 3.6 & 8.0 & 5.6 & .4 & 0 & 0 & 0 & 0 & 0 \\
\hline 450 & .1 & .5 & 1.8 & 4.9 & 9.8 & 7.5 & .8 & 0 & 0 & 0 & 0 & 0 \\
\hline 500 & .4 & 1.3 & 3.7 & 7.7 & 13.0 & 14.9 & 3.1 & 0 & 0 & 0 & 0 & 0 \\
\hline 550 & .8 & 2.4 & 5.8 & 10.8 & 16.4 & 17.4 & 3.6 & 0 & 0 & 0 & 0 & 0.2 \\
\hline
\end{tabular}

3) Daily discharges from both the East Fork and West Fork Eklutna Creeks show a distinct diurnal fluctuation: the low flow of the day occurs in mid-morning and the high flow of the day occurs in the evening.

4) During the 1986,1987 , and 1988 water years, between 77 and 84 percent of the total runoff from the East Fork Eklutna Creek basin occurred from June 1 to September 30 . The principal components of runoff during this period were snowmelt (53-63 percent), rainfall (27-29 percent), and icemelt (6-13 percent).

5) During the 1986,1987 , and 1988 water years, between 87 and 96 percent of the total runoff from the West Fork Eklutna Creek basin occurred from June 1 to September 30 . The principal components of runoff during this period were snowmelt (52-64 percent), rainfall (27-33 percent), and icemelt (9-19 percent).
6) A USGS flow model, the Precipitation-Runoff Modeling System, simulated the general discharge trends of the East Fork and West Fork Eklutna Creeks. The model's computational scheme for determining icemelt appears reasonable; however, more development in the model is needed to represent a glacier's drainage system.

7) From 1985-87, total yearly sediment transported by the East Fork Eklutna Creek ranged from 22,300 to 36,500 tons, while total yearly sediment transported by the West Fork Eklutna Creek ranged from 46,700 to 54,600 tons. Bedload constitutes between 14 and 26 percent of the sediment for East Fork Eklutna Creek and between 7 and 10 percent of the sediment for West Fork Eklutna Creek.

8) Two sedimentation processes characterize Eklutna Lake: delta progradation and river plume dispersion. At the delta area, coarse 
sediment is accumulating at a rate of about 5 acre-ft/yr, while the finer sediments are accumulating at a rate of $74 \mathrm{acre}-\mathrm{ft} / \mathrm{yr}$. A distinct interflow plume is present in the lake from late June through August.

9) Eklutna Lake has an active storage ranging from 0 to 190,000 acre-ft. Approximately 80 percent of the water that enters Eklutna Lake is from the East Fork and West Fork Eklutna Creeks.

10) A storage frequency analysis of Eklutna Lake indicates that May and June are the months when the storage capacity of the lake will most likely be exceeded. However, the probability of storage being exceeded during these months is less than 10 percent at a withdrawal rate of $450 \mathrm{ft}^{3} / \mathrm{s}$.

\section{REFERENCES CITED}

Anderson, E.A., 1973, National Weather Service river forecast system--snow accumulation and ablation model: National Oceanic and Atmospheric Administration Technical Memo NWS-HYDRO-17.

Coffin, J.H. and Ashton, W.S., 1986, Suspended sediment budget of a glacial-fed lake, Eklutna Lake, Alaska, in Proceedings of the Cold Regions Hydrology Symposium, Fairbanks, Alaska, D.L. Kane (ed.): American Water Resources Association, p. 501-508.

Colby, B.R., 1956, Relationship of sediment discharge to streamflow: U.S. Geological Survey Open-File Report, 170 p.

Emmett, W.W., 1979, A field calibration of the sediment-trapping characteristics of the Helley-Smith bedload sampler: U.S. Geological Survey Open-File Report 79-411, 96 p.
Field, W.O. (ed.), 1975, Mountain glaciers of the northern hemisphere: Corps of Engineers, Cold Regions Research and Engineering Laboratory, v. 2, 932 p.

Fountain, A.G., and Tangborn, W.V., 1985, The effect of glaciers on streamflow variations: Water Resources Research, v. 21, no. 4 , p. $579-586$.

Friedman, G.M., and Sanders, J.E., 1978, Principles of sedimentology: New York, John Wiley, 792 p.

Glover, K.C., 1984, Storage analysis for ephemeral streams in semiarid regions: U.S. Geological Survey Water-Resources Investigations Report 83-4078, 55 p.

Helley, E.J., and Smith, W., 1971, Development and calibration of a pressure-difference bedload sampler: U.S. Geological Survey Open-File Report, 18 p.

Hubbell, D.W., 1987, Bedload sampling and analysis, in Thorne, C.R., Bathurst, J.C., and Hey, R.D., (eds.), Sediment transport in gravel-bed rivers: New York, John Wiley.

Karlstrom, T.N.V., 1965, Upper Cook Inlet area and Matanuska River Valley, in Péwé, T.L., Ferrians, O.J., Jr., Nichols, D.R., and Karlstrom, T.N.V., Guidebook for field conference $\mathrm{F}$, central and south-central Alaska, International Association for Quaternary Research, 7th Congress, Fairbanks, 1965: Lincoln, Nebraska Academy of Sciences, p. 114-141 (reprinted 1977, Alaska Division of Geological Geophysical Surveys).

Lara, J.M., and Pemberton, E.L., 1963, Initial unit weight of deposited sediments: Proceedings of the Federal Inter-Agency Sedimentation Conference, U.S. Department of Agriculture Miscellaneous Publication No. 70, p. 818-845. 
Leavesley, G.H., Lichty, R.W., Troutman, B.M., and Saindon, L.G., 1983, PrecipitationRunoff Modeling System: User's manual: U.S. Geological Survey Water-Resources Investigations Report 83-4238, 207 p.

Mayo, L.R., Meier, M.F., and Tangborn, W.V., 1972, A system to combine stratigraphic and annual mass-balance systems--A contribution to the International Hydrological Decade: Journal of Glaciology, v. 11 , no. 61, p. 3-14.

Mayo, L.R., and Trabant, D.C., 1979, Effects of altitude on transposition of hydrologic data for Alaska: Handout to UNESCO Work Group Meeting on Northern Research Basin, Quebec, 12 p.

Meier, M.F., 1969, Glaciers and water supply: Journal of the American Water Works Association, v. 61, no. 1, p. 8-12.

Meier, M.F., and Post, Austin, 1962, Recent variations in mass net budgets of glaciers in western North America: International Association of Scientific Hydrology, Commission of Snow and Ice, Colloque d'Obergurgl, Publication No. 58, p. 6377.

Meier, M.F., and Tangborn, W.V., 1961, Distinctive characteristics of glacier runoff: U.S. Geological Survey Professional Paper 424-B, p. 14-16.

Meier, M.F., Tangborn, W.V., Mayo, L.R., and Post, A., 1971, Combined ice and water balances of Gulkana and Wolverine Glaciers, Alaska, and South Cascade Glacier, Washington, 1965 and 1966 Hydrologic Years: U.S. Geological Survey Professional Paper 715-A, 23 p.

Pelto, M.S., 1988, The annual balance of North Cascade Glaciers, Washington, U.S.A., measured and predicted using an activity-index method: Journal of Glaciology, v. 34, no. 117, p. 194-199.

Porterfield, George, 1972, Computation of fluvial-sediment discharge: U.S. Geological Survey Techniques of Water-Resources Investigations, book 3, chapter C3, 66 p.

Riggs, H.C., and Hardison, C.H., 1973, Storage analysis for water supply: U.S. Geological Survey Techniques of Water-Resources Investigations, book 4, chapter B2, 20 p.

Tangborn, W.V., Mayo, L.R., Scully, D.R., and Krimmel, R.M., 1977, Combined ice and water balances of Maclure Glacier, California, South Cascade Glacier, Washington, and Wolverine and Gulkana Glaciers, Alaska, 1967 Hydrologic Year: U.S. Geological Survey Professional Paper 715-B, 20 p.

Trabant, D.C., and Mayo, L.R., 1985, Estimation and effects of internal accumulation of five glaciers in Alaska: Annals of Glaciology, v. 6, p. 113-117.

U.S. Army Corps of Engineers, 1979, Volume 1--Summary report, Metropolitan Anchorage Urban Study: Municipality of Anchorage, $210 \mathrm{p}$.

U.S. Geological Survey, 1977, National handbook of recommended methods for watẹr-data acquisition--chap. 3, Sediment: U.S. Geological Survey, p. 3-1 - 3-100.

1986-89, Water resources data for Alaska--water years 1985-88: U.S. Geological Survey Water-Data Reports AK-85-1 to AK-88-1 (published annually).

Young, G.J., ed., 1985, Techniques for prediction of runoff from glacierized areas: International Association of Hydrological Sciences, Publication No. 149. 


\section{GLOSSARY}

Ablation - Melt of snow, firn, or ice.

Accumulation area ratio (AAR) - The area of accumulation of a glacier divided by the total glacier area.

Annual balance - The change in thickness of a glacier at a point from October 1 to September 30. Water equivalent depth is used throughout.

Average annual balance - The integrated annual balance over the glacier surface divided by the glacier area.

Bottomset bed - Fine-grained material (usually silts and clays) slowly deposited on the bed of quiescent body of water and which may in time be buried by foreset beds and topset beds.

Delta - A deposit of sediment formed where moving water (as from a stream at its mouth) is slowed by a body of standing water.

Density current - A highly turbid and relatively dense current which usually moves along the bottom of a body of standing water. Also referred to as a turbidity current.
Equilibrium line altitude (ELA) - The line on a glacier that divides the area of positive annual balance (high altitude) from the area of negative annual balance (low altitude). This is at approximately $4,000 \mathrm{ft}$ on the Eklutna Glacier.

Firn - Snow that has survived at least one summer.

Foreset bed - Inclined layers of sandy material deposited upon or along an advancing and relatively steep frontal slope. A foreset bed progressively covers a bottomset bed, and in turn is covered by a topset bed.

Internal accumulation - The process of liquid water freezing within a glacier. This happens in two ways. First, water left as capillary water at the end of summer freezes during winter. Second, the first water to penetrate the glacier freezes in the underlying cold snow and firn (Trabant and Mayo, 1985).

Topset bed - A layer of sediments deposited on the top surface of an advancing delta which is continuous with the landward alluvial plain. 